\title{
Effect of COVID-19 pandemic on air quality: a study based on Air Quality Index
}

\author{
Sadhan Gope ${ }^{1}$ (D) Subhojit Dawn ${ }^{2} \cdot$ Shreya Shree Das ${ }^{1}$ \\ Received: 21 May 2020 / Accepted: 14 May 2021 / Published online: 25 May 2021 \\ (C) The Author(s), under exclusive licence to Springer-Verlag GmbH Germany, part of Springer Nature 2021
}

\begin{abstract}
The COVID-19 pandemic has significantly affected economic activities all around the world. Though it took a huge amount of human breathes as well as increases unemployment, it puts a positive impression on the environment. To stop the speedy extend of this disease, the maximum Government has imposed a strict lockdown on their citizens which creates a constructive impact on the atmosphere. Air pollutant concentration has been investigated in this study to analyze the impact of lockdown on the environment. Based on the air pollutant concentration, Air Quality Index (AQI) is deliberated. The Air Quality Index indicates the most and least polluted cities in the world. A higher value of AQI represents the higher polluted city and a lesser value of Air Quality Index represents a less polluted city. The impact of lockdown on air quality has been studied in this work and it is observed that the air pollutant concentration has reduced in every city of the world during the lockdown period. It has been also detected that the $\mathrm{PM}_{2.5}$ and $\mathrm{PM}_{10}$ are the most affecting air concentrator which controls the air quality of all the selected places during and after lockdown.
\end{abstract}

Keywords Air Quality Index (AQI) - Particle pollution · Ground-level ozone $\left(\mathrm{O}_{3}\right) \cdot$ Carbon monoxide $(\mathrm{CO}) \cdot$ Nitrogen dioxide $\left(\mathrm{NO}_{2}\right) \cdot$ Sulphur dioxide $\left(\mathrm{SO}_{2}\right)$

Highlights

- COVID-19 is a pandemic declared by WHO.

- The effect of human happenings due to COVID-19 in 10 most polluted cities in the world was estimated after lockdown.

- Based on the air pollutant concentration, Air Quality Index (AQI) is calculated.

- $\mathrm{PM}_{2.5}$ is mostly responsible for major air pollution.

- $\mathrm{PM}_{10}, \mathrm{CO}, \mathrm{SO}_{2}, \mathrm{O}_{3}$, and $\mathrm{NO}_{2}$ are other major air pollutants.

Responsible Editor: Philippe Garrigues

Sadhan Gope

sadhan.nit@gmail.com

Subhojit Dawn

subhojit.dawn@gmail.com

Shreya Shree Das

shreyashree36@gmail.com

1 Department of Electrical Engineering, Mizoram University, Aizawl, India

2 Department of Electrical \& Electronics Engineering, Velagapudi Ramakrishna Siddhartha Engineering College, Vijayawada, Andhra Pradesh, India

\section{Introduction}

The major resources of the earth make human life feasible without which no one can sustain. Every living body on this earth requires air, water, sunlight, and food every day to continue its growth. It is unimaginable to live without these necessities of life. So, it is very significant to preserve and use them in a proper way. Nowadays, technologies are developed worldwide in a rapid manner for human progression. But the world has to accept the challenges which remain undefined and unpredictable. In this twenty-first century, society is facing a new challenge named coronavirus or COVID-19, which was discovered in the Wuhan province of China in the year 2019 (WHO 2020). Coronavirus or COVID-19 is a sporadic type virus that infects human beings, and commonly causes a respiratory infection to differ from the common cold to novel severe diseases such as severe acute respiratory syndrome (SARS). The usual symptoms seen in COVID-19 disease are sickness, fatigue, or dry cough. The easy and quick spread nature of COVID-19 threatened the whole world. This virus has infected a large population all over the globe. As of 10 March 2021, a total number of 118,161,892 people from 221 countries are infected by this disease (Worldometer 2020). As 
precautions, maximum countries have taken various steps to control the rate of spread of COVID-19, like schools and colleges are kept closed, traveling by public transport is not allowed, the non-essential commercial is shut down, and mass gatherings are not allowed. Social distancing should be maintained and people are suggested to stay at home as COVID-19 is a transmissible disease. This pandemic is the worst experience in human life which affects their lifestyle also. Most of the countries have applied strict lockdown throughout the country as a precautionary measure.

The lockdown significantly impacts social and economic activities but it has temporarily improved the air quality in most of the polluted cities in the world (Singh and Chakraborty 2020). Bad air quality results in several health issues in the living bodies throughout the globe. Every year, millions of people die due to this air pollution. Mainly five major air pollutants are regulating the clean air in the environment. These pollutants are particle pollution (particulate matter $\mathrm{PM}_{2.5}$ and $\left.\mathrm{PM}_{10}\right)$, nitrogen dioxide $\left(\mathrm{NO}_{2}\right)$, ground-level ozone $\left(\mathrm{O}_{3}\right)$, carbon monoxide $(\mathrm{CO})$, and sulphur dioxide $\left(\mathrm{SO}_{2}\right.$ ) (AirNow 2020). Out of these five pollutants, $\mathrm{PM}_{2.5}$ produces hazardous health issues such as lower respiratory infection (LRI) and chronic obstructive pulmonary disease (COPD) due to its microscopic particle size (Murray 2019). Due to the mandatory lockdown implementation in all major cities in the world, the $\mathrm{PM}_{2.5}$ level is drastically decreasing compared to the scenario before lockdown in the same places. Lockdown restricts the people movement and industry shutdown which results in a 25-60\% reduction in $\mathrm{PM}_{2.5}$ level (IQAir 2020). Due to $\mathrm{NO}_{2}$ pollution, approx. 4 million children are affected by asthma every year out of which $64 \%$ occur in urban centers (Pattanun et al. 2019). $\mathrm{NO}_{2}$ is also responsible for producing some harmful secondary pollutants such as ozone $\left(\mathrm{O}_{3}\right)$ and nitric acid $\left(\mathrm{HNO}_{3}\right)$ which can damage human life (Tobías et al. 2020). A significant reduction (approx. $45 \%$ to $50 \%$ ) of $\mathrm{NO}_{2}$ is noted after the worldwide lockdown. This mainly occurred due to the reduction of traffic emissions in urban cities (Yaron 2020). Air pollution generates many adverse effects in our social, economic, and natural environment. The major concern of air pollution is for public health and environmental challenges (Haines et al. 2017). Recently, a significant reduction in air pollution has been observed globally which is only possible due to the lockdown of most countries and cities (Muhammad et al. 2020).

In the very recent past, some researchers have studied the impact of COVID-19 on air quality throughout the world. On 23 March 2020, the Govt. of India has declared full lockdown throughout the country to mitigate the speedy feast of the coronavirus. This announcement creates some positive as well as some negative impacts on human society. Mahato et al. (2020) present a study of air quality in the lockdown situation by choosing Delhi, India, as a case study location. $\mathrm{PM}_{2.5}$ and $\mathrm{PM}_{10}$ have been chosen by the authors for air quality assessment. As per the studies, the values of $\mathrm{PM}_{2.5}$ and $\mathrm{PM}_{10}$ have reduced by $50 \%$ compared with the prelockdown conditions. Ramesh P and Chauhan (2020) exhibit a study to check the air quality all over India in the lockdown period using satellite and ground observations. The value of Air Quality Index, $\mathrm{PM}_{2.5}$, and tropospheric $\mathrm{NO}_{2}$ concentration is decayed due to the lockdown. Manob et al. (2020) examine the impacts of lockdown on $\mathrm{PM}_{2.5}$ (ambient aerosols) with considering the Indo-Gangetic Plain Cities. As per their studies, the value of $\mathrm{PM}_{2.5}$ has reduced to 79 from 179 across the selected cities after the lockdown. Sahoo et al. (2020a, 2020b) show the effect of COVID-19 on meteorological parameters of air. Some major cities of Chandigarh and Punjab have been chosen by the authors for the related study. After completing the studies, the authors have concluded that environmental pollution can be controlled by a temporary lockdown. The influence of COVID-19 on the environment in several places of India has also been studied in (Sahoo et al. 2020a, b; Pratima et al. 2020a, b; Sharma et al. 2020; S J et al. 2020). In maximum studies, $\mathrm{PM}_{2.5}, \mathrm{PM}_{10}, \mathrm{NOx}$, and $\mathrm{CO}$ have been taken for calculating the Air Quality Index (AQI). From all the studies, it is clear that air quality is improved after the implementation of lockdown (during the COVID pandemic) which directly improves the health conditions of human beings (Manob et al. 2021). The COVID-19 pandemic improved the air quality not only in India but is also observed in several countries of the world like Malaysia (Abdullah et al. 2020), Rio de Janeiro of Brazil (Dantas et al. 2020), China (Filonchyk et al. 2020; Xu et al. 2020), Iran (Broomandi et al. 2020), Ecuador (Zalakeviciute et al. 2020), Almaty of Kazakhstan (Kerimray et al. 2020), etc. From all the previous study, it reveals that the environment has improved throughout the globe. Dutheil et al. (2020), Bherwani et al. (2020), and Sahoo et al. (2020b) also present the impacts of lockdown in the environment in terms of air quality.

As per the author's knowledge, several researchers have already studied the effect of lockdown on air quality throughout the world, but no one has covered up all the points combined which have been discussed in this study. The main contribution of this study is as follows:

(a) The ten most polluted cities have been chosen for the study. This selection is totally based on the number of COVID-19 cases (as of June 2020), the extent of lockdown process, and the availability of air pollution data.

(b) The air pollutant data (i.e., particle pollution, groundlevel ozone, nitrogen dioxide, carbon monoxide, and sulphur dioxide) before and during lockdown has been taken from several sources for selected 10 cities.

(c) The AQI has been calculated by using the collected data with lockdown and without lockdown conditions. The health conditions during that period have also been studied. 
(d) To check the effectiveness of our study (mathematical calculations, scenarios), the real-time air quality has also been collected from several sources.

(e) This study presents the air quality scenario around the globe for three conditions: before lockdown, during lockdown, and after lockdown.

\section{Air Quality Index}

The government agencies use an Air Quality Index (AQI) to give information about air pollution to the public. The higher value of AQI indicates the higher air pollution level and higher health alarming condition. The AQI is mainly classified into six sets based on the values of the index. Each set represents a different level of health concern. The six sets of AQI are good, moderate, sensitive group, unhealthy, very unhealthy, and maroon. Table 1 represents the AQI for public health risk. From Table 1, it is clear that AQI value up to 50 represents good air, and above 300 represents harmful air (AirNow 2020). So, some precautions must be taken for every citizen to maintain their good health when AQI values are increased.

The air quality basically depends on the concentration of pollutants and atmospheric conditions. AQI equation is used to convert air pollutant concentration into Air Quality Index. The mathematical expression of AQI is as follows (Mintz 2016):

$\mathrm{A}_{\mathrm{QI}}=\frac{I_{\max }-\mathrm{I}_{\min }}{C_{\max }-C_{\min }}\left(P_{c}-C_{\min }\right)+I_{\min }$

Here, $\mathrm{A}_{\mathrm{QI}}$ is the Air Quality Index for pollutants.

$P_{c}$ is the concentration of pollutants.

$C_{\max }$ is the concentration breakpoint that is greater than or equal to $P_{\mathrm{c}}$.

$C_{\min }$ is the concentration breakpoint that is less than or equal to $P_{\mathrm{c}}$.

$I_{\max }$ is the index breakpoint corresponding to $C_{\max }$.

$I_{\min }$ is the index breakpoint corresponding to $C_{\min }$.

The details of the breakpoint and air pollutant limits have been taken from Mintz (2016). If multiple air pollutants are available in a single monitoring station, then AQI value for that location is taken as the largest value of AQI reported in the specified site irrespective of any particular pollutants.

\section{Selection of pollutant and location}

Generally, the Air Quality Index (AQI) is calculated by assessing the five air pollutant concentrations, i.e., particle pollution (known as particulate matter including $\mathrm{PM}_{2.5}$ and $\left.\mathrm{PM}_{10}\right)$, ground-level ozone $\left(\mathrm{O}_{3}\right)$, nitrogen dioxide $\left(\mathrm{NO}_{2}\right)$, carbon monoxide $(\mathrm{CO})$, and sulphur dioxide $\left(\mathrm{SO}_{2}\right)$. All the air pollutant except ground-level ozone $\left(\mathrm{O}_{3}\right)$ have primary sources while ground-level ozone $\left(\mathrm{O}_{3}\right)$ is formed in the presence of sunlight and mostly it is emitted from the primary sources of the atmosphere. In this study $\mathrm{PM}_{2.5}, \mathrm{PM}_{10}, \mathrm{O}_{3}$, $\mathrm{NO}_{2}, \mathrm{CO}$, and $\mathrm{SO}_{2}$ air pollutants are considered to calculate AQI. Ten major polluted cities in the world based on the number of COVID-19 cases (as of June 2020), the extent of lockdown process, and the availability of air pollution data have been selected for our studies.

The average data has been taken based on a 3-week lockdown period for each city and compares it to the same period before lockdown conditions. Based on IQAir 2020 report (June 2020), the ten most polluted cities are Delhi, Mumbai, New York, London, Los Angeles, Madrid, Seoul, Rome, Sao Paulo, and Wuhan. The lockdown period for Delhi, Mumbai, New York, London, Los Angeles, Madrid, and Sao Paulo is considered from 23 March to 13 April, whereas for Seoul from 26 February to 18 March, for Rome from 9 March to 30 March, and for Wuhan from 3 February to 24 February 2020. We have used the World Air Quality Index portal (available at www.aqien.org), World Air Map (available at https://air.plumelabs.com), and Air Pollution in the World website (available at https://aqicn.org/city/newyork) to record the air pollution data for the abovementioned cities. It is to be noted that the data for the above websites are handled by any private institution or govt. body of the respective countries, so the collected data may not be fully validated. For confirmation of this data, some other sources have been also considered, which is shown in the later section of the study.

\section{Data collection and analysis}

In one word, COVID-19 has destroyed the entire globe in all social, economical, and educational prospects except environmental. The lockdown due to the COVID-19 is the reason for

Table 1 Air Quality Index for public health risk

\begin{tabular}{|c|c|c|c|c|c|}
\hline $0-50$ & $51-100$ & $101-150$ & $151-200$ & $201-300$ & $>300$ \\
\hline Good & Moderate & Sensitive group & Unhealthy & Very unhealthy & Maroon \\
\hline No-risk & $\begin{array}{l}\text { The risk for some } \\
\text { people }\end{array}$ & $\begin{array}{l}\text { The public is likely to be } \\
\text { affected }\end{array}$ & $\begin{array}{l}\text { Serious health effect for } \\
\text { sensitive group }\end{array}$ & $\begin{array}{l}\text { The health effect is increased for } \\
\text { everyone }\end{array}$ & $\begin{array}{l}\text { Everyone is likely to be } \\
\text { affected }\end{array}$ \\
\hline
\end{tabular}


Fig. 1 Boat traffic at Venice, Northern Italy, during April 2019 and April 2020
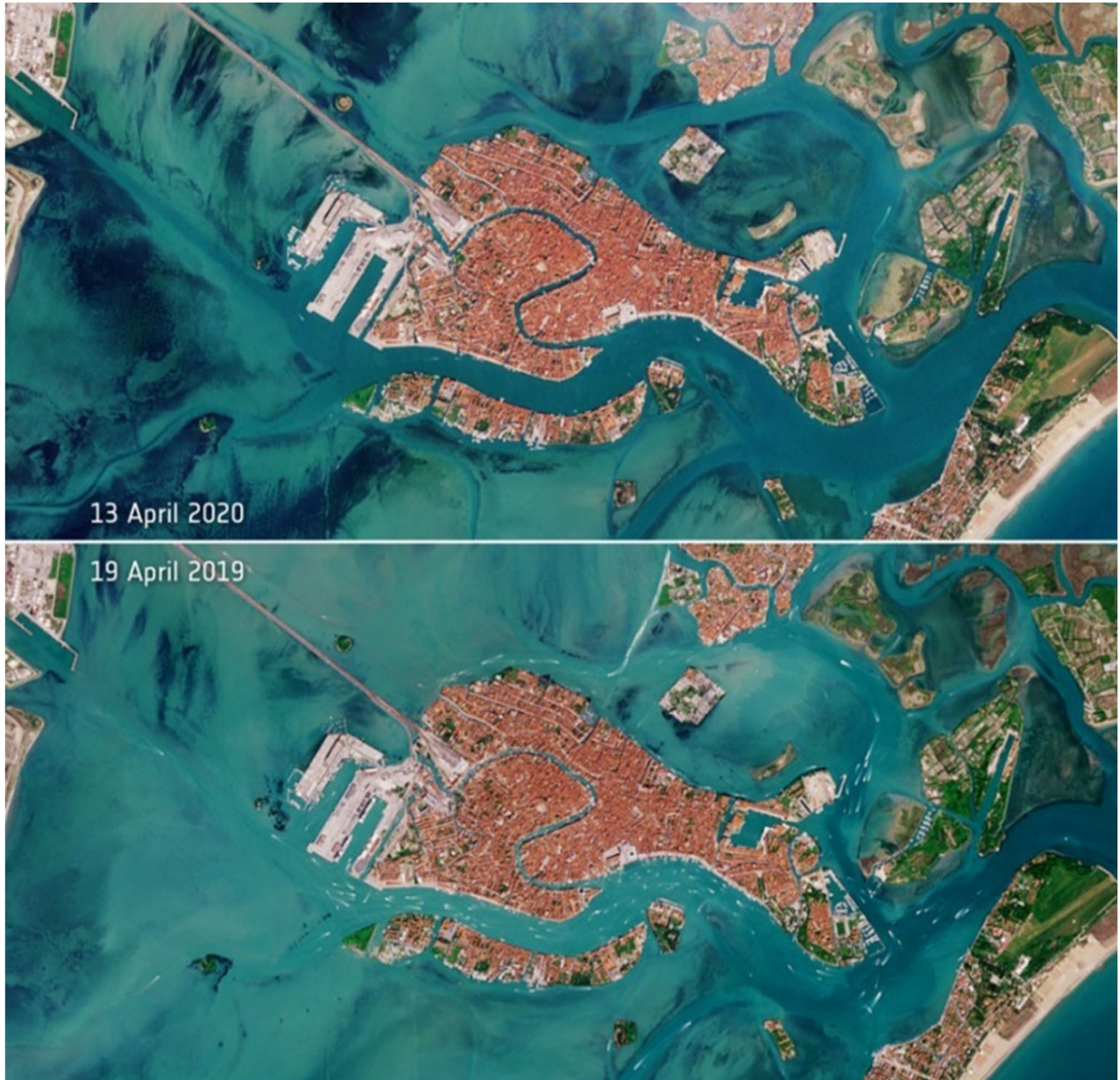

improving the quality of air, soil, and water in the environment. Maximum governing body imposes the lockdown to their citizens by stopping the academic institutions, industries, transportation system, etc. Due to this, the quantity of every air pollutant particle has decreased as compared to normal time.

Figure 1 shows the boat traffic in Venice, Northern Italy, during April 2019 and April 2020. From the figure, it is clear that the boat traffic is reduced on 13 April 2020 which is due to the lockdown (Deserted Venetian lagoon 2020). And the water quality also improved during that period. This is one example of the improvement of the environment. The stoppage of the transportation system, as well as industries, improved the air quality which will also be discussed in the later part of the study. The effect of the lockdown on air quality is described in this part of the study. Here, all the particles involved in the air quality are considered one by one.

(A) Particular pollution $\left(\mathrm{PM}_{10}\right.$ and $\left.\mathrm{PM}_{2.5}\right)$

The mix of tiny solid and/or liquid particles deferred in the air refers to the particular pollution. Most of the particles are
Fig. 2 Average $\mathrm{PM}_{2.5}$ concentration with and without lockdown

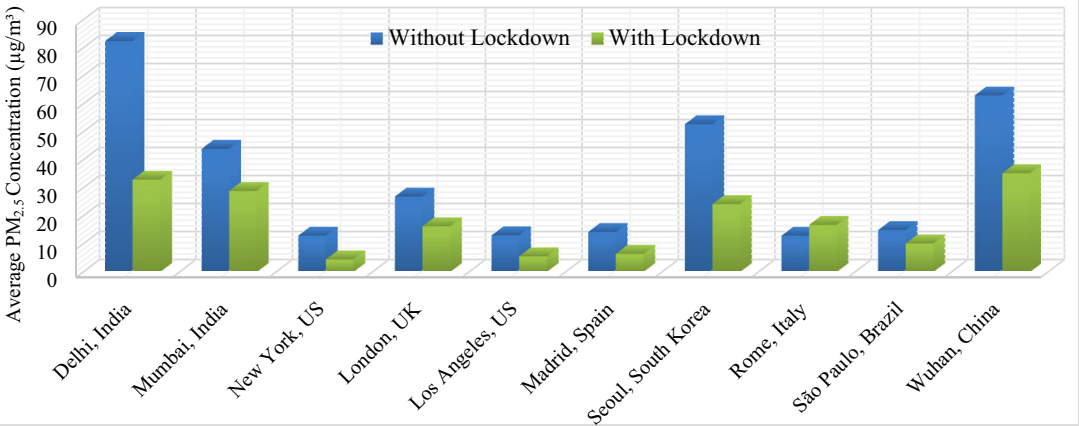


Fig. 3 Average $\mathrm{PM}_{10}$ concentration before and after lockdown

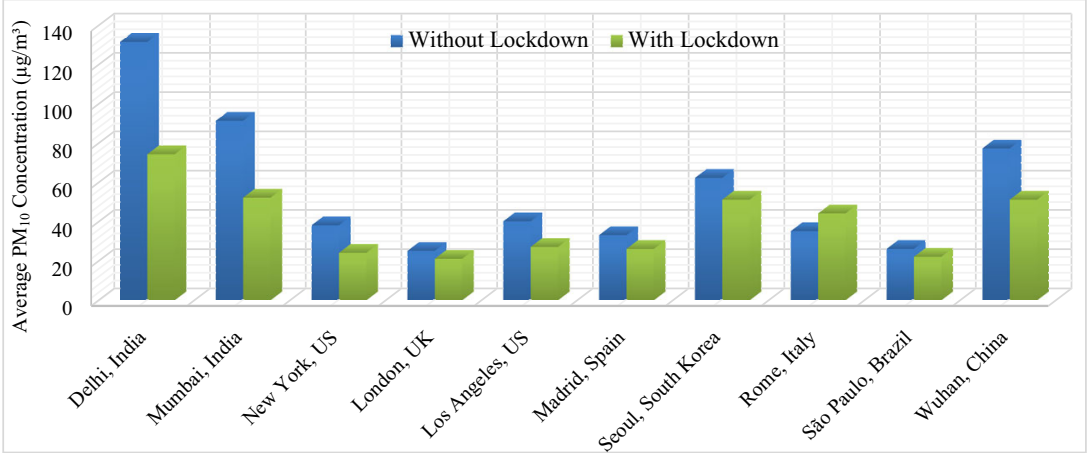

indistinguishable or very small in size. The air becomes opaque when the particles' levels are high. $\mathrm{PM}_{10}$ and $\mathrm{PM}_{2.5}$ are the main categories of air particles. $\mathrm{PM}_{10}$ particle diameter is generally 10 micrometers $(\mu \mathrm{m})$ or smaller, whereas particle diameter is $2.5 \mu \mathrm{m}$ or smaller for $\mathrm{PM}_{2.5} \cdot \mathrm{PM}_{2.5}$ is the riskiest pollutant and it penetrates the greatest threat to the human respiratory system even in the bloodstream due to its small size. Figure 2 depicts that the average $\mathrm{PM}_{2.5}$ concentration is reduced in nine among the ten selected cities in the world. Rome is the one city whose $\mathrm{PM}_{2.5}$ concentration had increased in the lockdown period due to the burning of forests.

It can be observed from Fig. 2 that the average concentrations of $\mathrm{PM}_{2.5}$ in New York, Los Angeles, Madrid, and São Paulo are very low during the lockdown. As a result, these cities are having clean air. On the other hand, $\mathrm{PM}_{2.5}$ average concentration is remarkably high in the cities like Delhi, Mumbai, Seoul, and Wuhan.

Figure 3 epitomizes the average concentration of $\mathrm{PM}_{10}$ for the abovementioned cities with and without lockdown conditions. Maximum reduction of average $\mathrm{PM}_{10}$ concentration is observed in Delhi, Mumbai, and Wuhan cities due to the strict lockdown. Average $\mathrm{PM}_{10}$ concentration approximately $25 \%$ increases in Rome during the lockdown. A reliable reduction in average $\mathrm{PM}_{10}$ concentration is observed in New York, London, Los Angeles, Madrid, and São Paulo during the lockdown.

(B) Ground-level ozone $\left(\mathrm{O}_{3}\right)$

Ozone $\left(\mathrm{O}_{3}\right)$ is formed and demolished in the existence of nitrogen oxides (NOx) and volatile organic compound (VOC) materials. Out of the five major air pollutants, ozone is only
Fig. 4 Average $\mathrm{O}_{3}$ concentration with and without lockdown

Fig. 5 Average $\mathrm{CO}$ concentration with and without lockdown
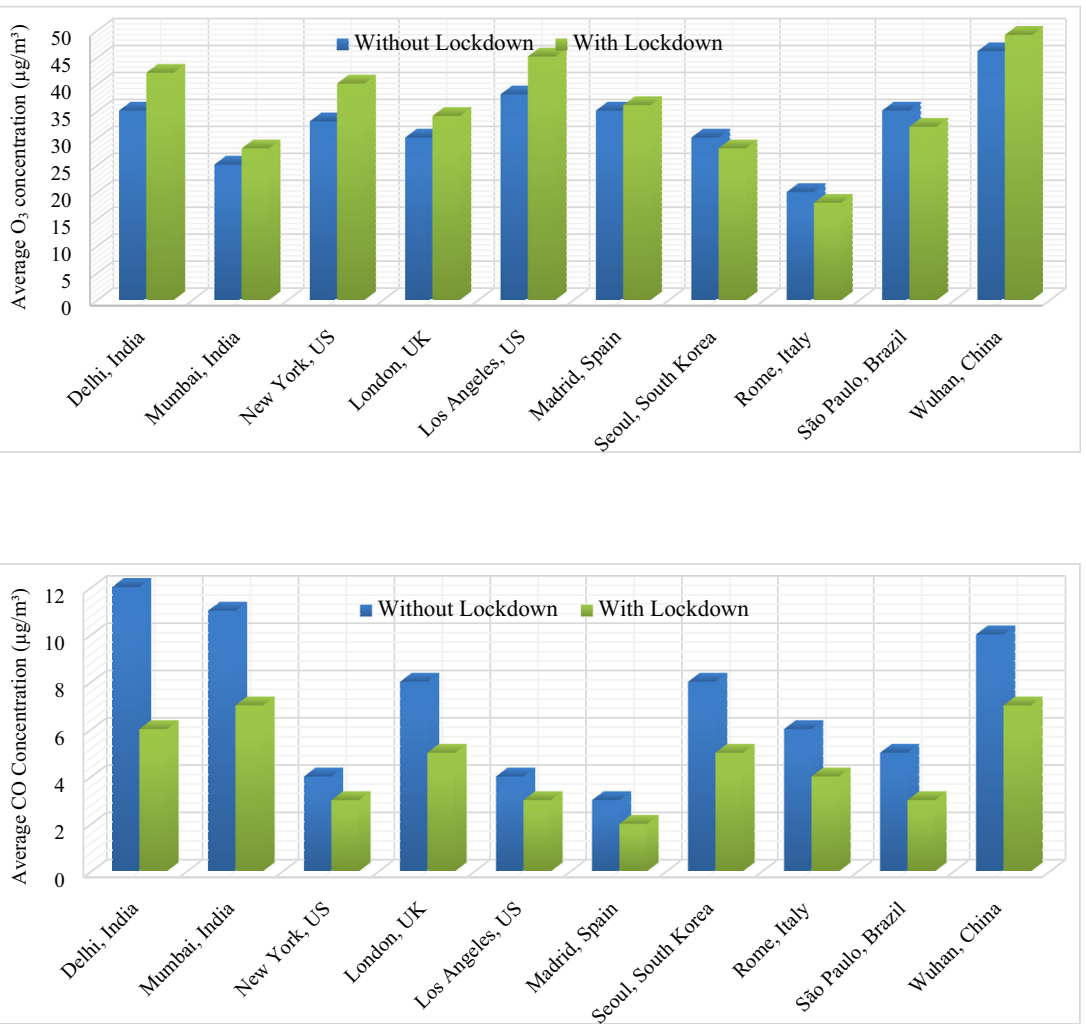
Fig. 6 Average $\mathrm{NO}_{2}$ concentration with and without lockdown

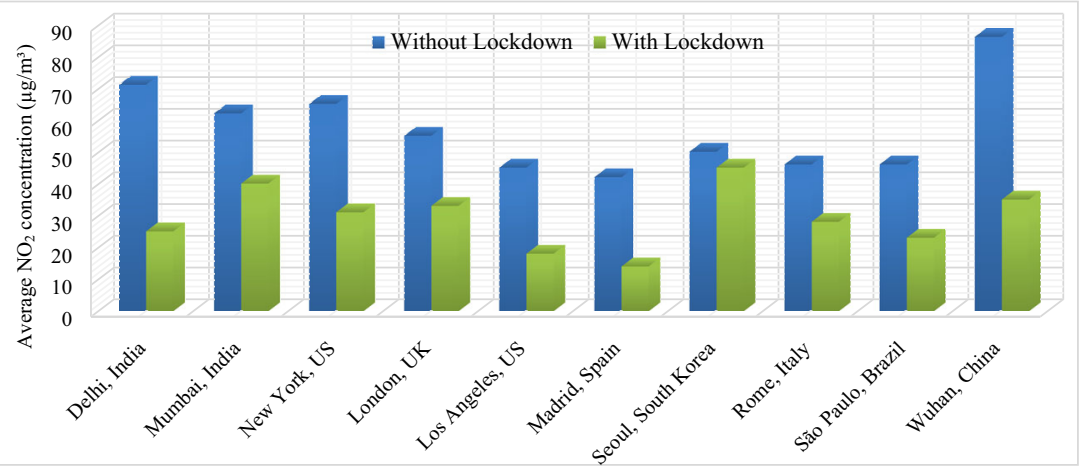

the secondary air pollutant. Figure 4 demonstrates the average ozone concentration with and without lockdown conditions in the selected cities. From Fig. 4, it is observed that ozone concentration has increased in maximum cities after the lockdown. Only in Rome that ozone concentration is decreased around $10 \%$. Maximum average ozone concentration increases are seen in Delhi $(+17 \%)$, New York $(+21 \%)$, and Los Angeles $(+18 \%)$ during the lockdown. This may be due to the more sunlight and availability of NOx and VOCs during the lockdown condition.

(C) Carbon monoxide (CO)

The majority of the carbon monoxide $(\mathrm{CO})$ is emanated from mobile sources such as motor vehicles, locomotives,

Fig. 7 Average $\mathrm{SO}_{2}$ concentration with and without lockdown

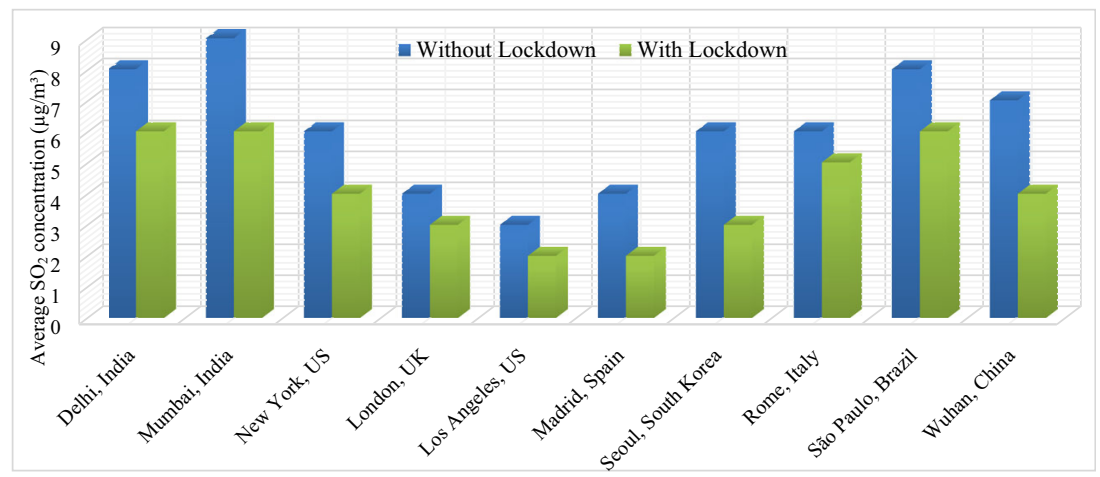

Table 2 AQI value and status of the city without lockdown

\begin{tabular}{|c|c|c|c|c|c|c|c|}
\hline City, country & $\begin{array}{l}\text { AQI due to } \\
\mathrm{PM}_{2.5}\end{array}$ & $\begin{array}{l}\text { AQI due to } \\
\mathrm{PM}_{10}\end{array}$ & $\begin{array}{l}\text { AQI due to } \\
\mathrm{CO}\end{array}$ & $\begin{array}{l}\text { AQI due to } \\
\mathrm{SO}_{2}\end{array}$ & $\begin{array}{l}\text { AQI due to } \\
\mathrm{NO}_{2}\end{array}$ & $\begin{array}{l}\text { AQI due to } \\
\mathrm{O}_{3}\end{array}$ & Remark \\
\hline Delhi, India & 165 & 89 & 117 & 4 & 36 & 16 & Unhealthy and responsible pollutant is $\mathrm{PM}_{2.5}$ \\
\hline $\begin{array}{l}\text { Mumbai, } \\
\text { India }\end{array}$ & 121 & 69 & 103 & 5 & 31 & 12 & $\begin{array}{l}\text { Unhealthy for sensitive group and responsible } \\
\text { pollutant is } \mathrm{PM}_{2.5}\end{array}$ \\
\hline $\begin{array}{l}\text { New York, } \\
\text { USA }\end{array}$ & 52 & 35 & 40 & 3 & 32 & 15 & Moderate and responsible pollutant is $\mathrm{PM}_{2.5}$ \\
\hline London, UK & 82 & 23 & 76 & 2 & 27 & 14 & Moderate responsible pollutant is $\mathrm{PM}_{2.5}$ \\
\hline $\begin{array}{l}\text { Los Angeles } \\
\text { USA }\end{array}$ & 53 & 37 & 40 & 2 & 22 & 17 & Moderate and responsible pollutant is $\mathrm{PM}_{2.5}$ \\
\hline Madrid, Spain & 55 & 30 & 32 & 2 & 21 & 16 & Moderate and responsible pollutant is $\mathrm{PM}_{2.5}$ \\
\hline $\begin{array}{l}\text { Seoul, South } \\
\text { Korea }\end{array}$ & 142 & 54 & 76 & 3 & 25 & 14 & $\begin{array}{l}\text { Unhealthy for sensitive group and responsible } \\
\text { pollutant is } \mathrm{PM}_{2.5}\end{array}$ \\
\hline Rome, Italy & 52 & 32 & 58 & 3 & 23 & 9 & Moderate and responsible pollutant is $\mathrm{CO}$ \\
\hline $\begin{array}{l}\text { São Paulo, } \\
\text { Brazil }\end{array}$ & 57 & 24 & 49 & 4 & 23 & 16 & Moderate and responsible pollutant is $\mathrm{PM}_{2.5}$ \\
\hline Wuhan, China & 155 & 62 & 93 & 4 & 43 & 21 & Unhealthy and responsible pollutant is $\mathrm{PM}_{2.5}$ \\
\hline
\end{tabular}


Table 3 AQI value and status of the city with lockdown

\begin{tabular}{|c|c|c|c|c|c|c|c|}
\hline City, country & $\begin{array}{l}\text { AQI due to } \\
\mathrm{PM}_{2.5}\end{array}$ & $\begin{array}{l}\text { AQI due to } \\
\mathrm{PM}_{10}\end{array}$ & $\begin{array}{l}\text { AQI due to } \\
\mathrm{CO}\end{array}$ & $\begin{array}{l}\text { AQI due to } \\
\mathrm{SO}_{2}\end{array}$ & $\begin{array}{l}\text { AQI due to } \\
\mathrm{NO}_{2}\end{array}$ & $\begin{array}{l}\text { AQI due to } \\
\mathrm{O}_{3}\end{array}$ & Remark \\
\hline Delhi, India & 95 & 60 & 58 & 3 & 12 & 19 & Moderate and responsible pollutant is $\mathrm{PM}_{2.5}$ \\
\hline Mumbai, India & 86 & 48 & 67 & 3 & 20 & 13 & Moderate and responsible pollutant is $\mathrm{PM}_{2.5}$ \\
\hline $\begin{array}{l}\text { New York, } \\
\text { USA }\end{array}$ & 18 & 22 & 30 & 2 & 15 & 18 & Good and responsible pollutant is $\mathrm{CO}$ \\
\hline London, UK & 60 & 19 & 49 & 2 & 16 & 16 & Moderate and responsible pollutant is $\mathrm{PM}_{2.5}$ \\
\hline $\begin{array}{l}\text { Los Angeles } \\
\text { USA }\end{array}$ & 23 & 25 & 30 & 1 & 9 & 21 & $\begin{array}{l}\text { Good and ideal for air, the responsible } \\
\text { pollutant is } \mathrm{CO}\end{array}$ \\
\hline Madrid, Spain & 27 & 24 & 19 & 1 & 7 & 17 & $\begin{array}{l}\text { Good and ideal for air, the responsible } \\
\text { pollutant is } \mathrm{PM}_{2.5}\end{array}$ \\
\hline $\begin{array}{l}\text { Seoul, South } \\
\text { Korea }\end{array}$ & 76 & 47 & 49 & 2 & 22 & 13 & Moderate and responsible pollutant is $\mathrm{PM}_{2.5}$ \\
\hline Rome, Italy & 61 & 41 & 40 & 3 & 14 & 8 & Moderate and responsible pollutant is $\mathrm{PM}_{2.5}$ \\
\hline $\begin{array}{l}\text { São Paulo, } \\
\text { Brazil }\end{array}$ & 42 & 20 & 30 & 3 & 11 & 15 & $\begin{array}{l}\text { Good and ideal for air, the responsible } \\
\text { pollutant is } \mathrm{PM}_{2.5}\end{array}$ \\
\hline Wuhan, China & 99 & 47 & 67 & 2 & 17 & 23 & Moderate and responsible pollutant is $\mathrm{PM}_{2.5}$ \\
\hline
\end{tabular}

airplanes, and other engines and equipment. Figure 5 portrays the average $\mathrm{CO}$ concentration of ten selected cities with and without lockdown conditions. From Fig. 5, it is detected that the concentration of average $\mathrm{CO}$ is decreased in all the cities after the lockdown due to COVID-19. The major reduction of $\mathrm{CO}$ after the lockdown is seen in Delhi $(-50 \%)$, Mumbai $(-36 \%)$, London $(-37 \%)$, Seoul $(-37 \%)$, Rome $(-33 \%)$, and São Paulo $(-40 \%)$ as compared to without lockdown condition.

(D) Nitrogen dioxide $\left(\mathrm{NO}_{2}\right)$

Like previous cases, the average concentration level of air pollutants has also decreased after the lockdown. Figure 6 epitomizes the average $\mathrm{NO}_{2}$ concentration of the ten selected cities with and without lockdown conditions. From Fig. 6, it is observed that there is a momentous drop of average $\mathrm{NO}_{2}$ concentration during the lockdown in Delhi (-65\%), New York (-52\%), Los Angeles (-60\%), Madrid (-66\%), São Paulo $(-50 \%)$, and Wuhan $(-59 \%)$ as compared to without lockdown conditions.

(E) Sulphur dioxide $\left(\mathrm{SO}_{2}\right)$

Sulphur dioxide is one of the largest air pollutants which are responsible for air pollution. Figure 7 signifies the average $\mathrm{SO}_{2}$ concentration of ten selected cities with and without lockdown conditions. From Fig. 7, it can be noted that the major reduction of average $\mathrm{SO}_{2}$ concentration during lockdown occurred in Mumbai (-33\%), New York $(-33 \%)$, Los Angeles
Fig. 8 Air Quality Index with and without lockdown

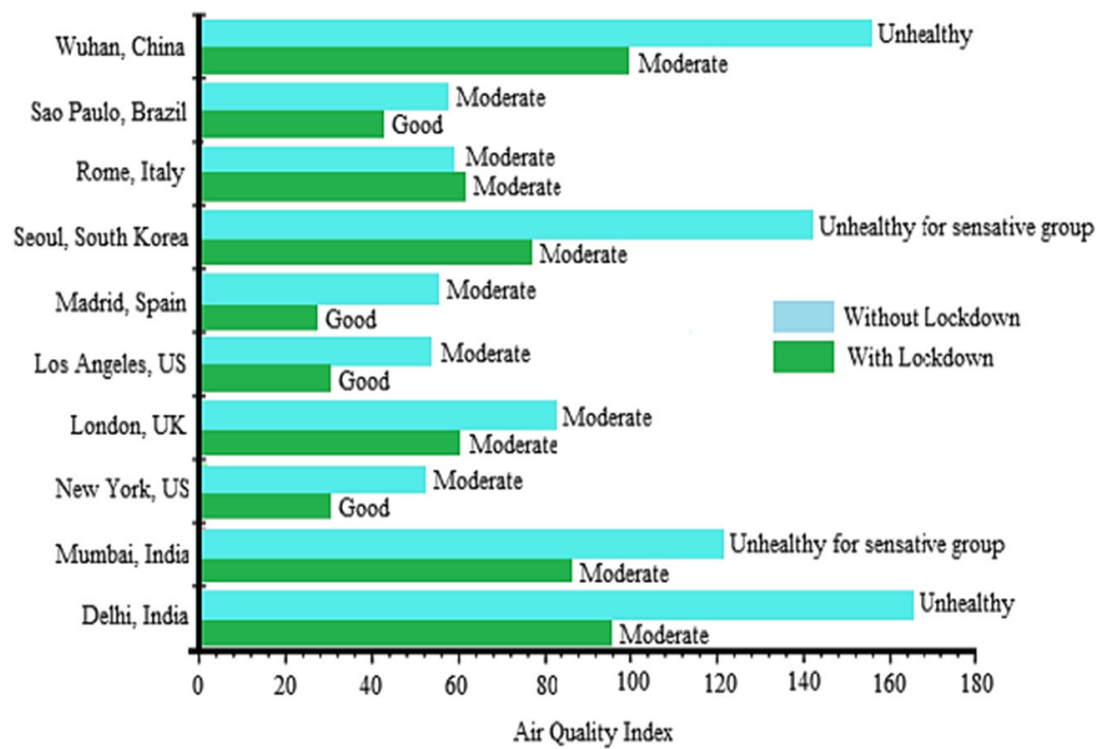


a

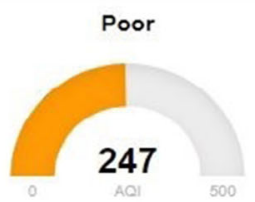

Anand Vihar, Delhi - DPCC

Prominent Pollutant is PM2.5

On Wednesday, 15 Jan 2020 02:00 PM

Pollutant
PM2.5
PM10
NO2
NH3
SO2
CO
OZONE

Timeline

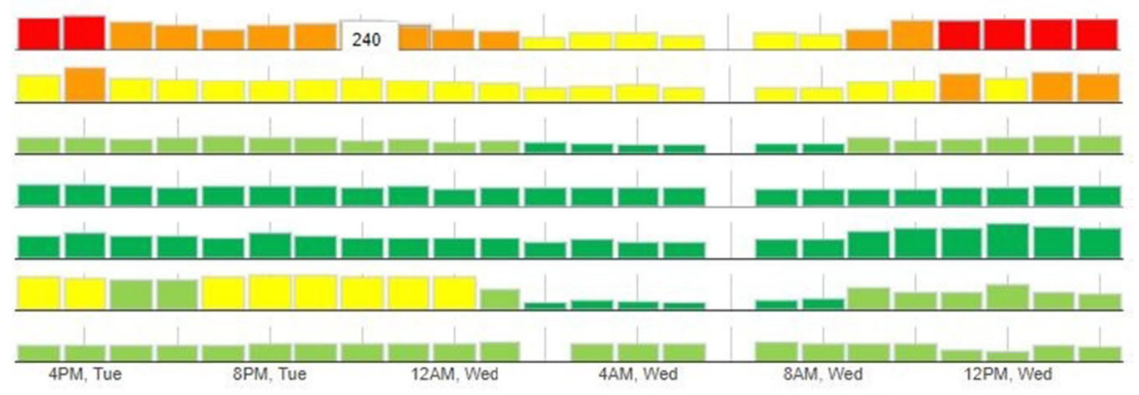

Moderate

Anand Vihar, Delhi - DPCC

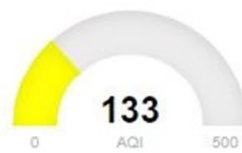

Prominent Pollutant is PM2.5

33

On Monday, 15 Jum 2020 02:00 PM
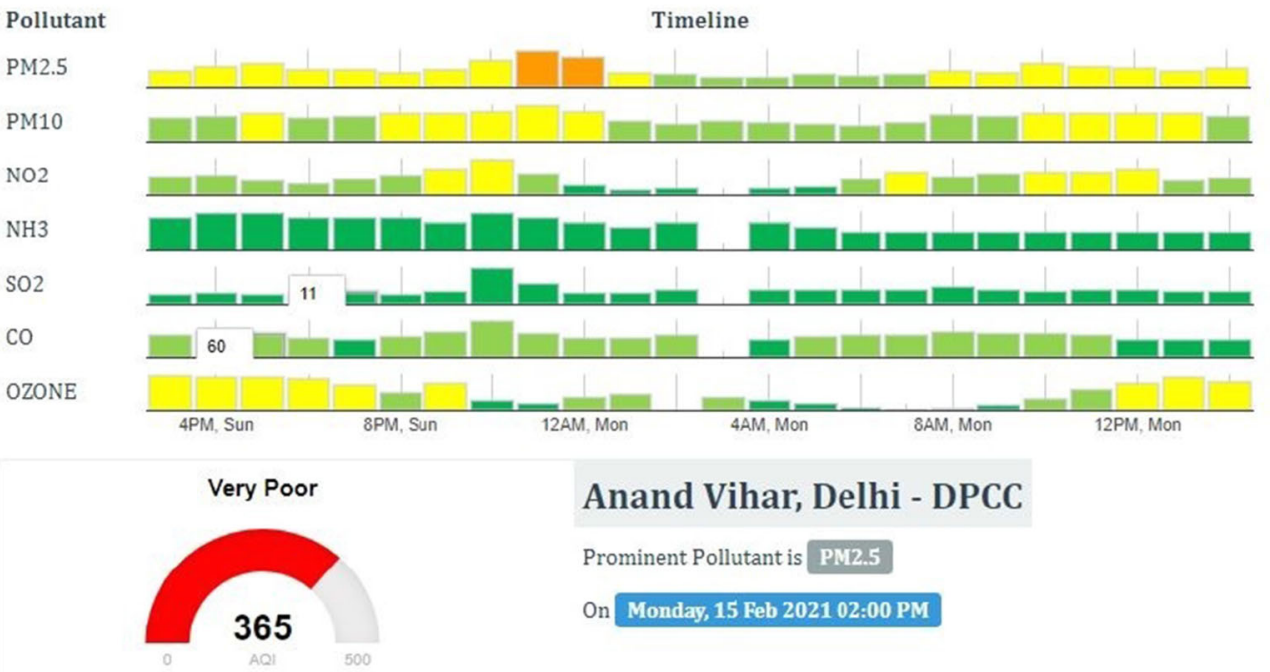

Anand Vihar, Delhi - DPCC

Prominent Pollutant is PN2.5

On Monday, 15 Feb 2021 02:00 PM

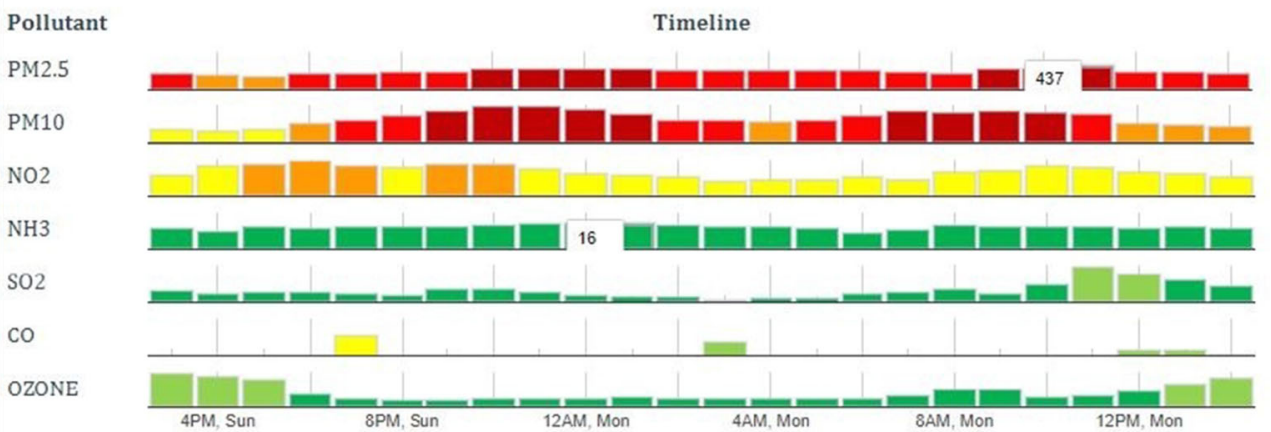

Fig. 9 Status of air quality in four metro cities of India with and without lockdown. (a) Status of air quality in Delhi with and without lockdown (b) Status of air quality in Kolkata with and without lockdown (c) Status of air quality in Mumbai with and without lockdown (d) Status of air quality in Bengaluru with and without lockdown 
b

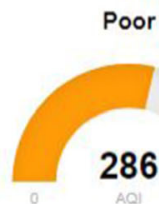

286

Pollutant

PM2.5

PM10

NO2

NH3

SO2

CO

OZONE

PM2.5

PM10

NO2

$\mathrm{NH} 3$

SO2

co

OZONE

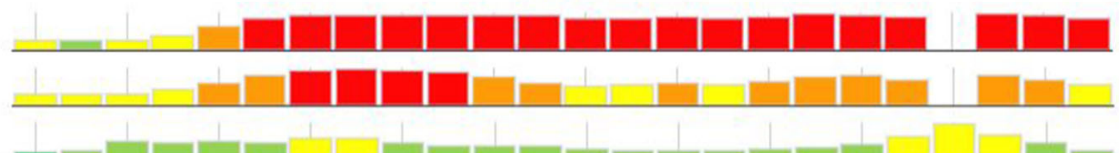

Jadavpur, Kolkata - WBPCB

Prominent Pollutant is PM2.5

On Wednesday, 15 Jan 2020 03:00 PM

Timeline

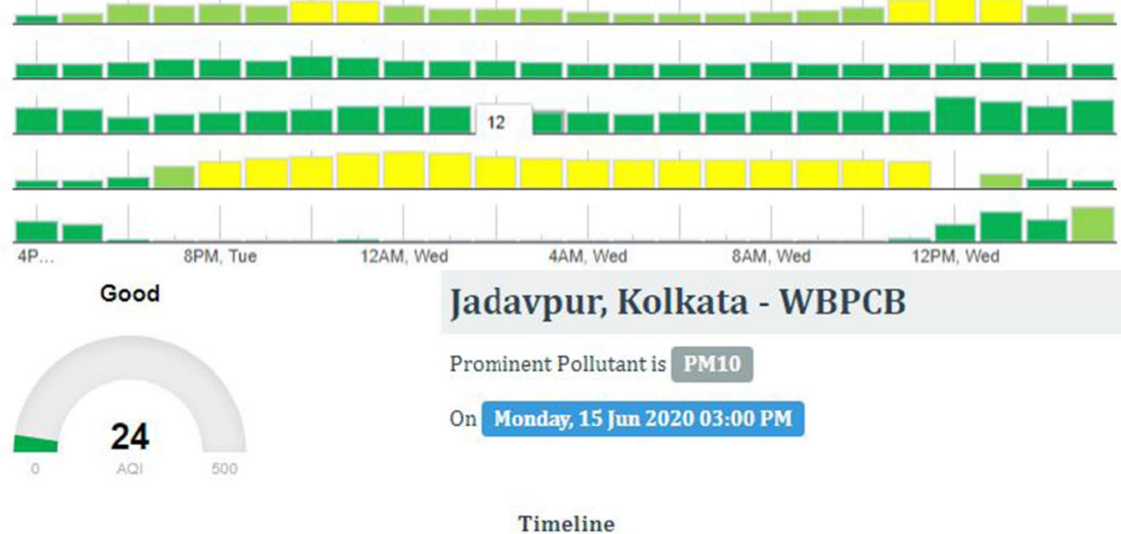

Timeline

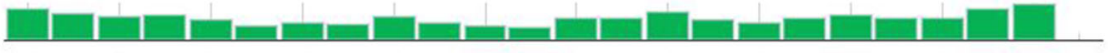

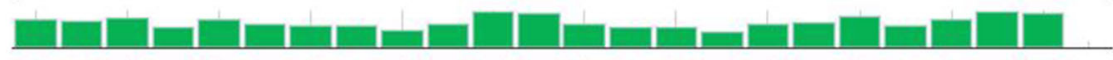

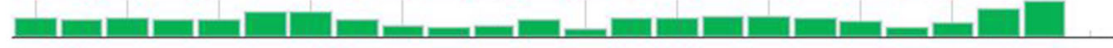
\begin{tabular}{l|l|l|l|l|l|l|l|l|l|l|}
\hline & $\square$
\end{tabular}

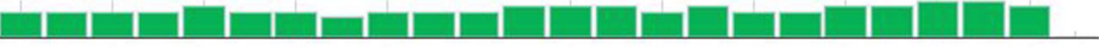

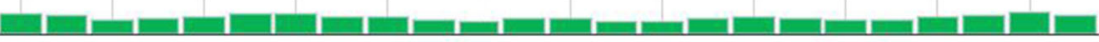
4P... Moderate Jadavpur, Kolkata - WBPCB
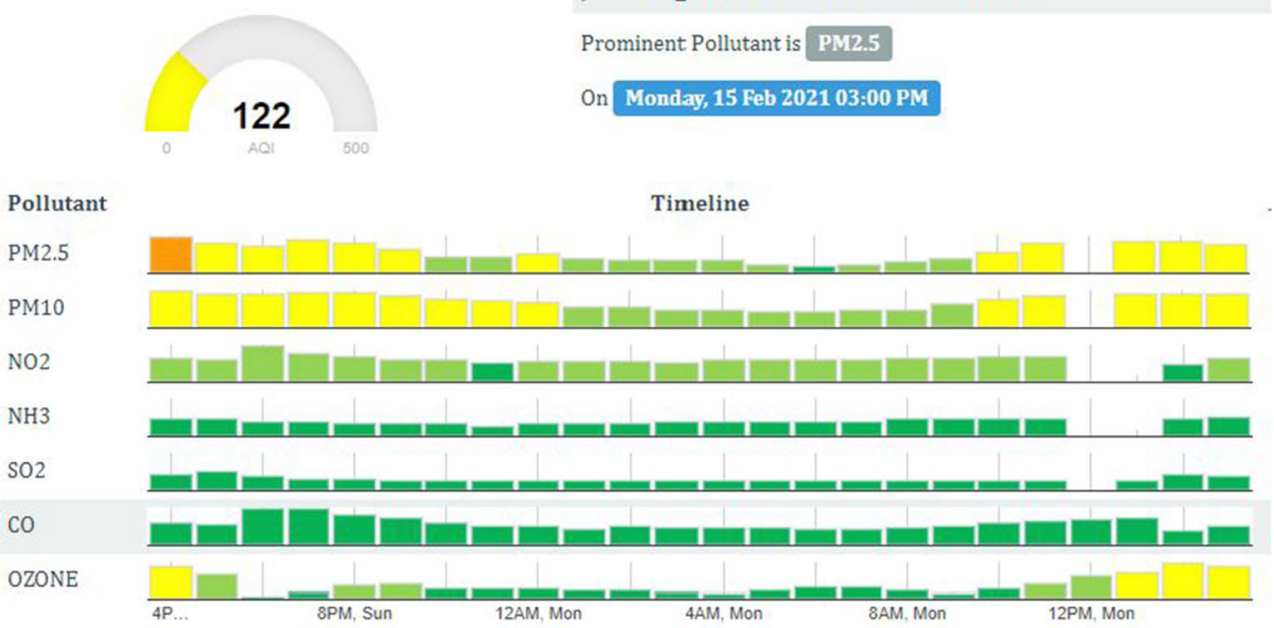

Fig. 9 continued. 
C

Moderate
\begin{tabular}{|c|c|}
\hline 126 & \\
\hline 0 & 1260
\end{tabular}

Kurla, Mumbai - MPCB

Prominent Pollutant is PM10

On Wednesiay, 15 Jan 2020 03:00 PM
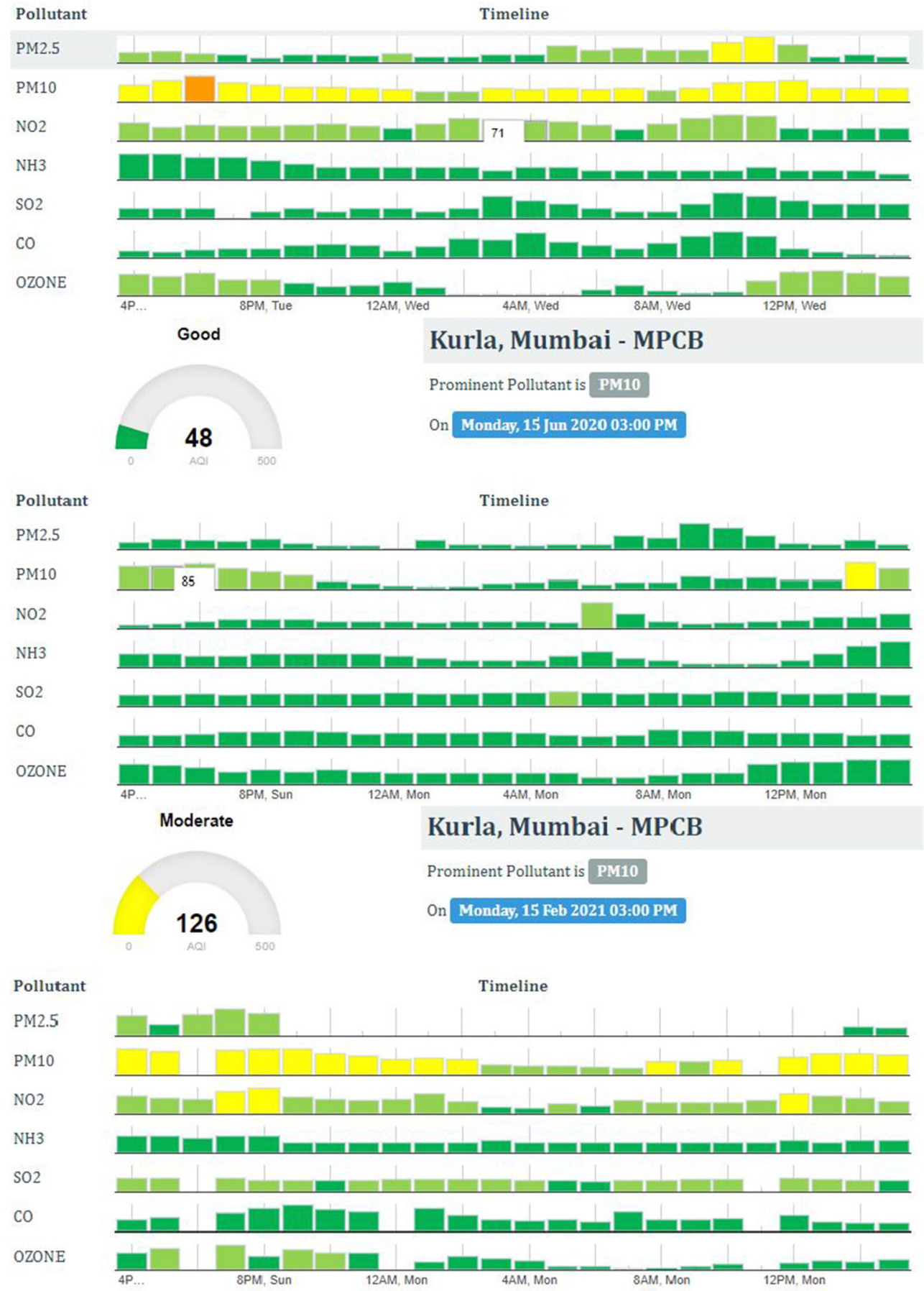

Fig. 9 continued. 
d

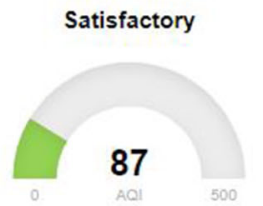

Silk Board, Bengaluru - KSPCB

Prominent Pollutant is PM10

On Saturday, 18 Jan 2020 03:00 PM

Pollutant
PM2.5
PM10
NO2
NH3
SO2
CO
OZONE

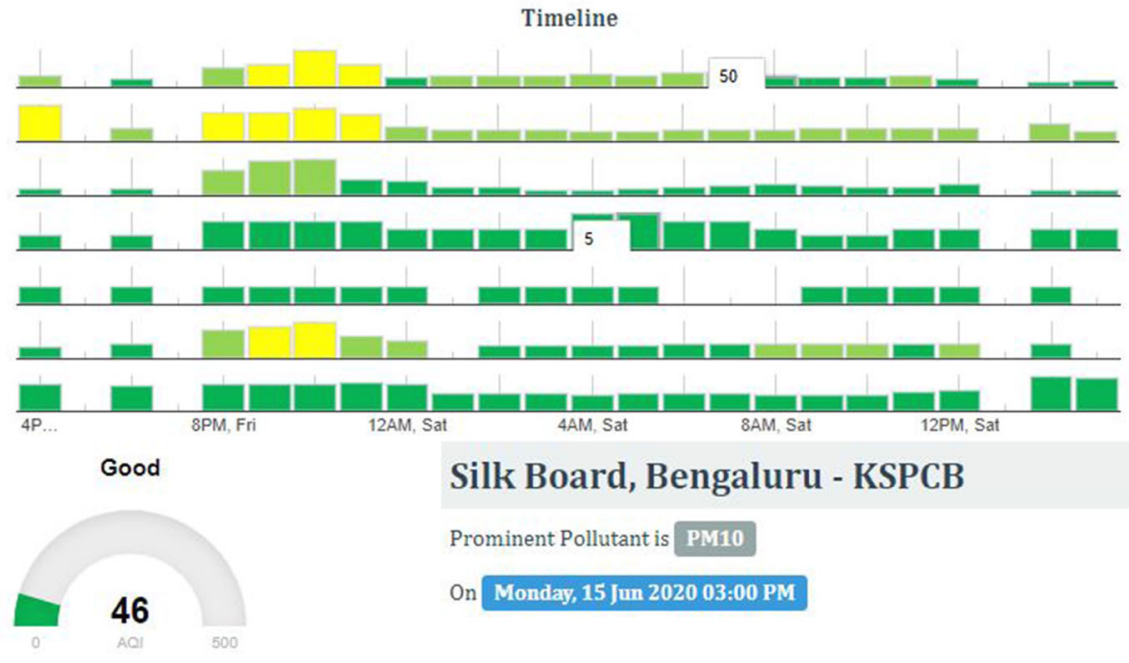

Pollutant

PM2.5

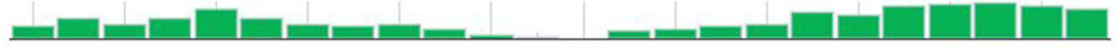

PM10

$+\mathrm{H}$

NO2

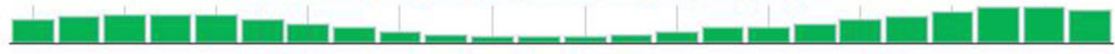

NH3

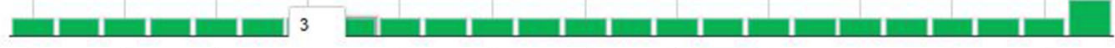

$\mathrm{SO} 2$

$\mathrm{CO}$ -

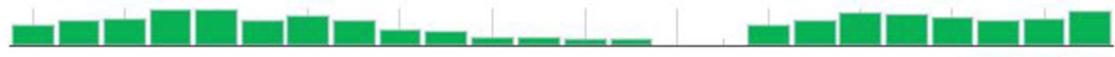

OZONE SP Silk Board, Bengaluru - KSPCB

Satisfactory

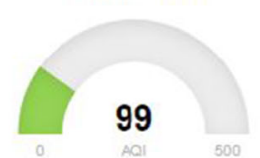

Pollutant

PM2.5

PM10

NO2

NH3

SO2

co

OZONE

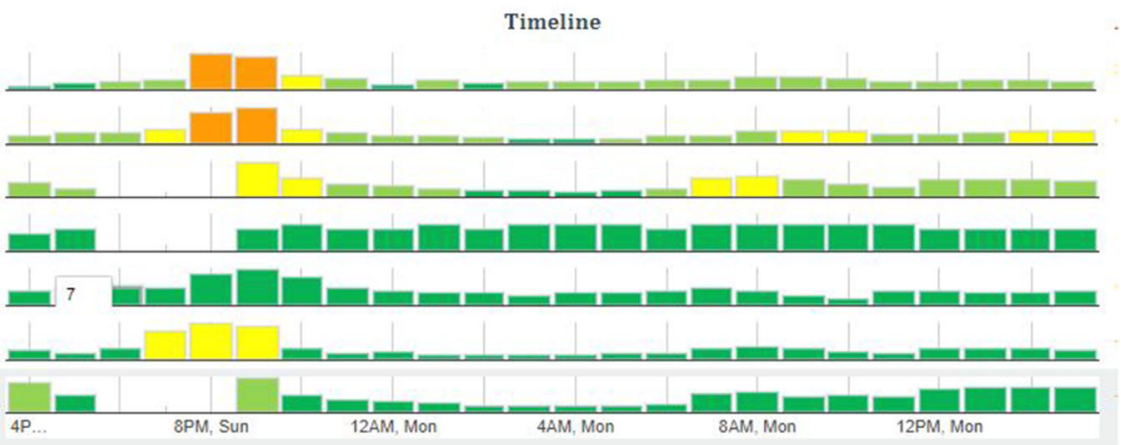

Fig. 9 continued. 
Fig. 10 Nitrogen dioxide concentrations over Europe with and without lockdown

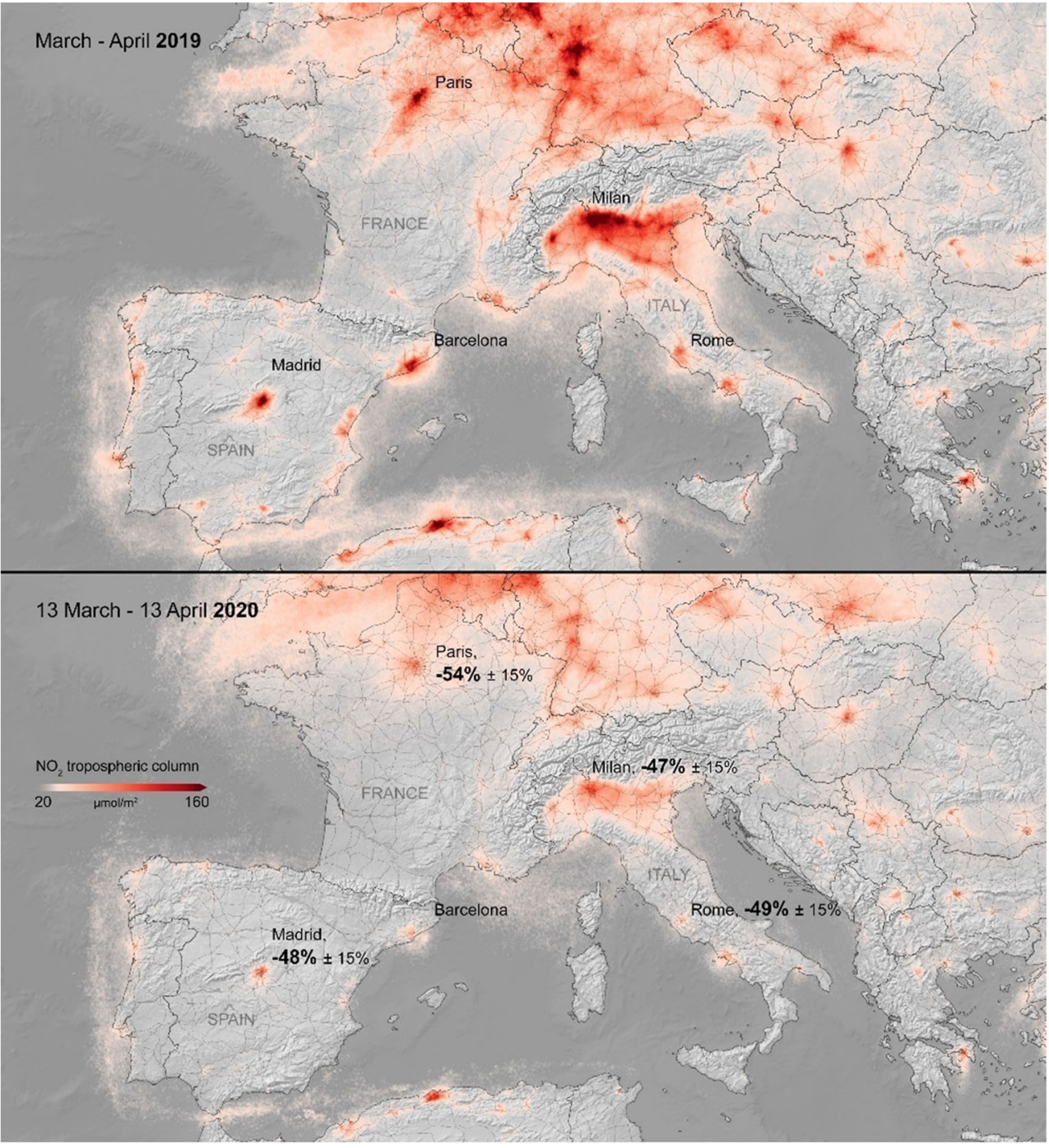

$(-33 \%)$, Madrid (-50\%), Seoul $(50 \%)$, and Wuhan $(-42 \%)$ compared to the without lockdown conditions.

It can be observed from the average air pollutant concentration data which has already been discussed in the previous part of the study that all the air pollutant concentrations decrease except the ozone pollutant during the lockdown as compared with the without lockdown condition. From the air pollutant concentration, we have designed the Air Quality Index (AQI) for all the pollutants responsible for air pollution using Eq. (1). Tables 2 and 3 show the calculated AQI value with individual air pollutants for all the selected places considering the without and with lockdown conditions respectively. From Table 2, it is observed that $\mathrm{PM}_{2.5}$ is responsible for major air pollution in all the cities except Rome. In
Fig. 11 Nitrogen dioxide concentrations over France with and without lockdown

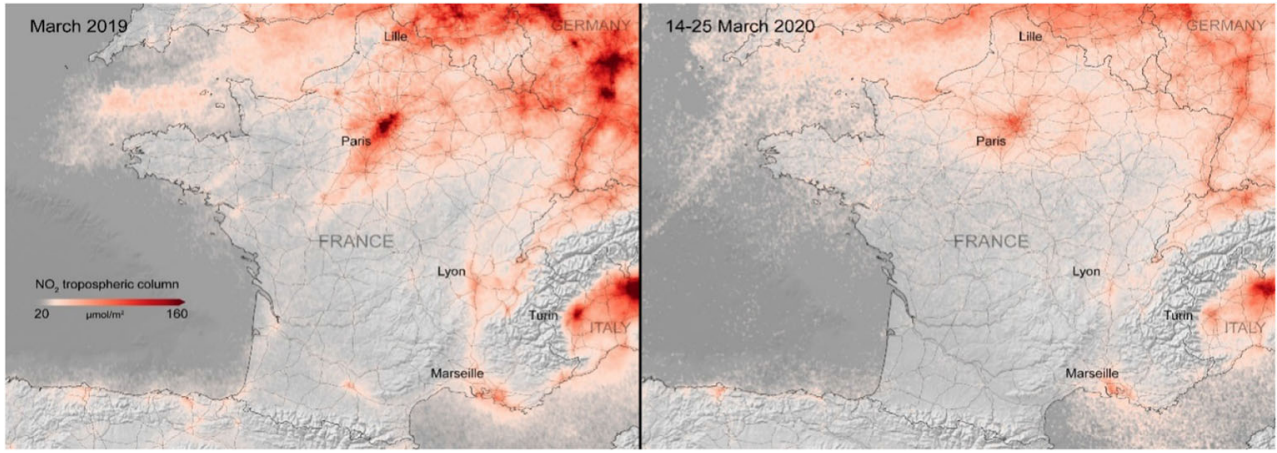




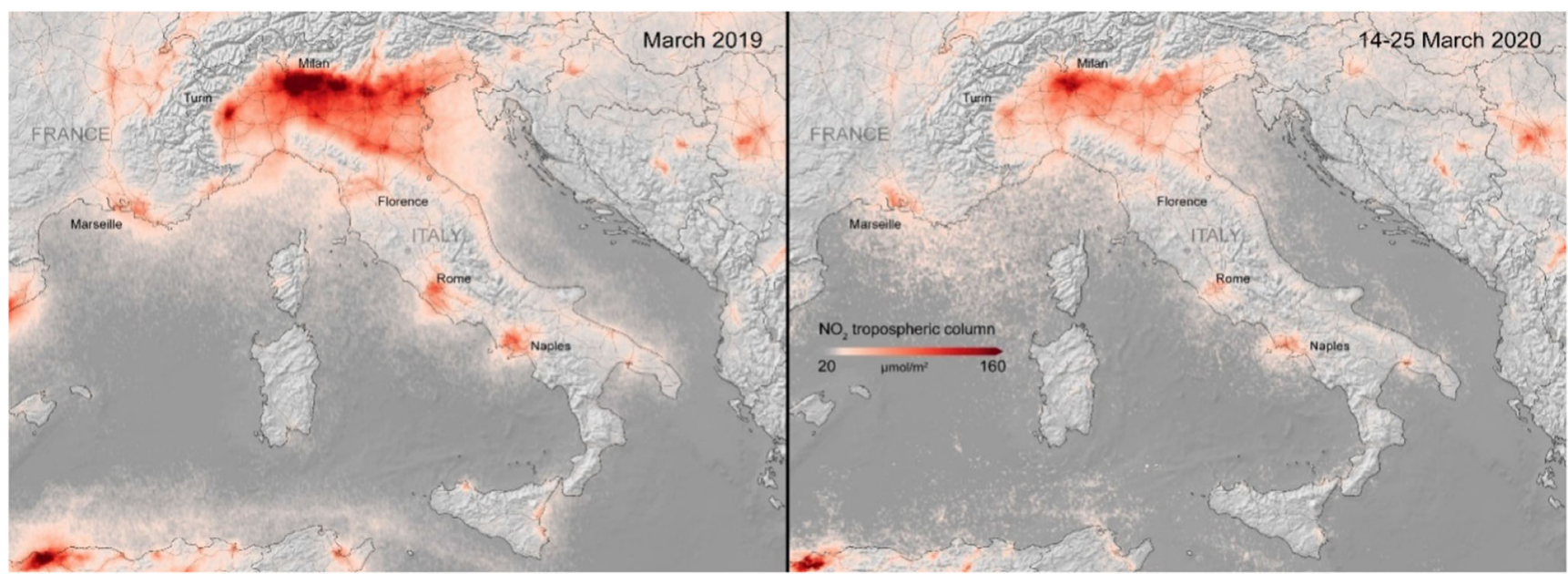

Fig. 12 Nitrogen dioxide concentrations over Italy with and without lockdown

Rome, $\mathrm{CO}$ is mainly accountable for air pollution. From Table 2, it is perceived that the air quality of Delhi and Wuhan are unhealthy and the general public may practice some serious health issues in these cities. Mumbai and Seoul's air quality is also unhealthy, but it is for some sensitive public and the other general public may not be affected in these cities. The air quality of the remaining six cities is moderate and it can be acceptable for all public.

From Table 3, it is detected that $\mathrm{PM}_{2.5}$ is responsible for major air pollution in almost all the cities except New York and Los Angeles. CO is mainly responsible for air pollution in New York and Los Angeles. From the table, it is also observed that the air quality of the six selected cities (i.e., Delhi, Mumbai, London, Seoul, Rome, and Wuhan) is moderate and the remaining four cities (i.e., New York, Los Angeles,
Madrid, and São Paulo) is good and all pollutions in these cities are little and the environment is risk-free.

Figure 8 epitomizes the states of AQI for the abovementioned cities with and without lockdown conditions. From Fig. 8, it is observed that the Air Quality Index is improved in almost all the cities except Rome and London. It is observed that the AQI of Delhi and Wuhan is shifted from "unhealthy" environment to "moderate" environment; the air quality of Mumbai and Seoul is also shifted from "unhealthy environment for sensitive publics" to "moderate" environment. Though London and Rome's air quality status is not changed, but AQI is slightly improved in these two cities during the lockdown period. In the remaining four cities (i.e., New York, Los Angeles, Madrid, and São Paulo), the AQI is shifted from a "moderate" environment to a "good" environment.
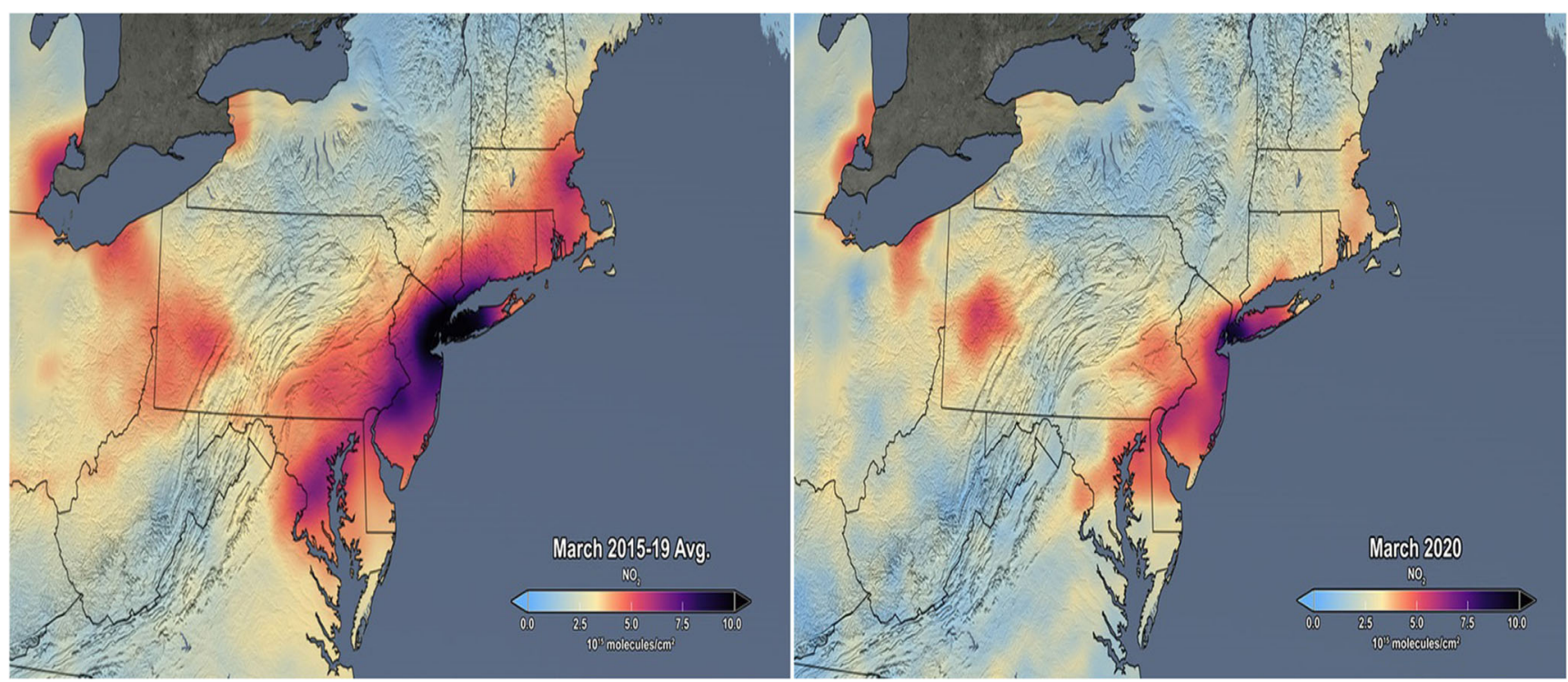

Fig. 13 Nitrogen dioxide concentrations over the northeast United States with and without lockdown 


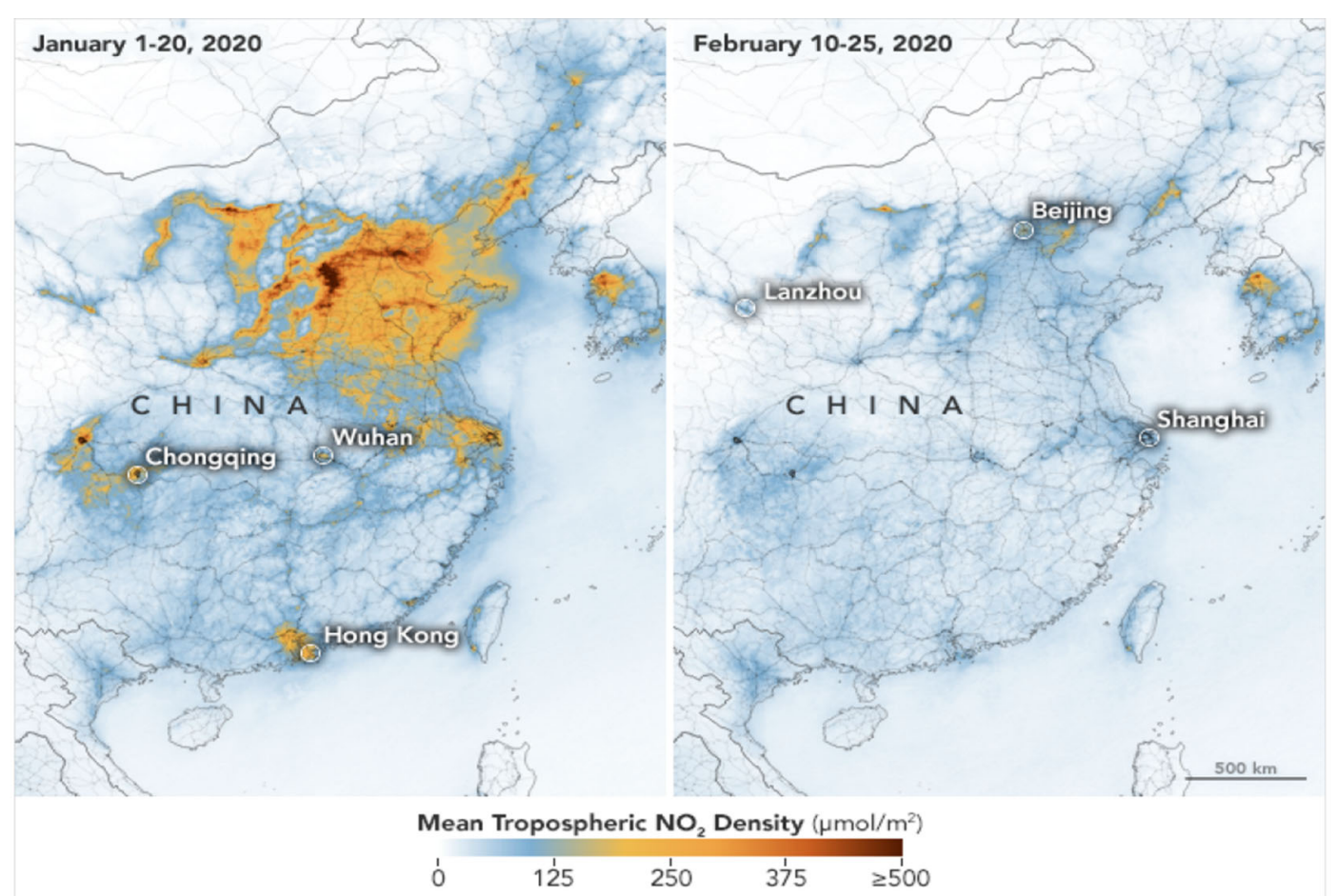

(a)
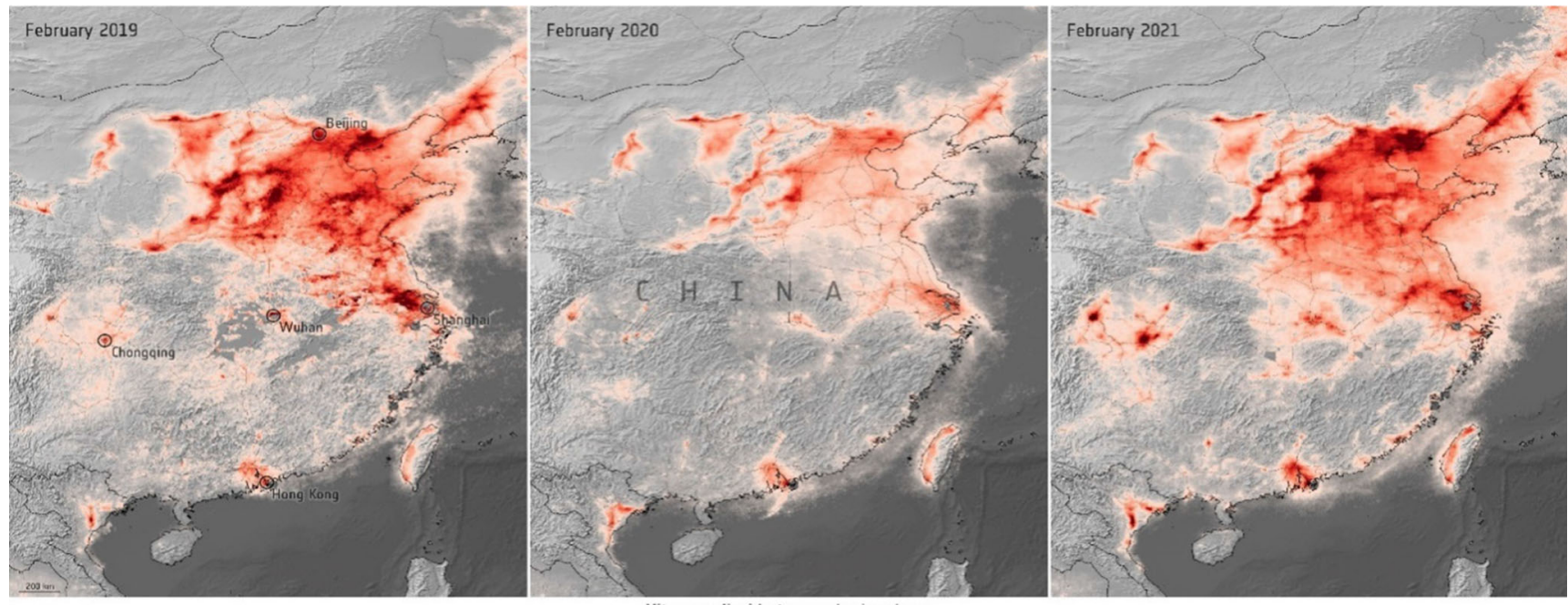

Nitrogen dioxide tropospheric column

20

(b)

Fig. 14 Nitrogen dioxide concentrations over China with and without lockdown. (a) Mean tropospheric $\mathrm{NO}_{2}$ density in 2020 (b) $\mathrm{NO}_{2}$ tropospheric column (c) Comparison in mean tropospheric $\mathrm{NO}_{2}$ density in 2019 and 2020

\section{Global air quality scenario during lockdown}

Among all the air pollutants, $\mathrm{PM}_{2.5}$ and $\mathrm{PM}_{10}$ take a leading role in any place's air quality. Due to the lockdown implementation by the maximum government, the air quality of all the places has improved significantly. This is possible due to the closure of industries, transportation systems, etc., in the lockdown period. Figure 9 presents the comparative studies of AQI in some metro cities of India (Delhi, Kolkata, Mumbai, and Bengaluru) before lockdown, during lockdown, and after lockdown (National Air Quality Index 2020). There are 3 different times that have been considered to check the impact 

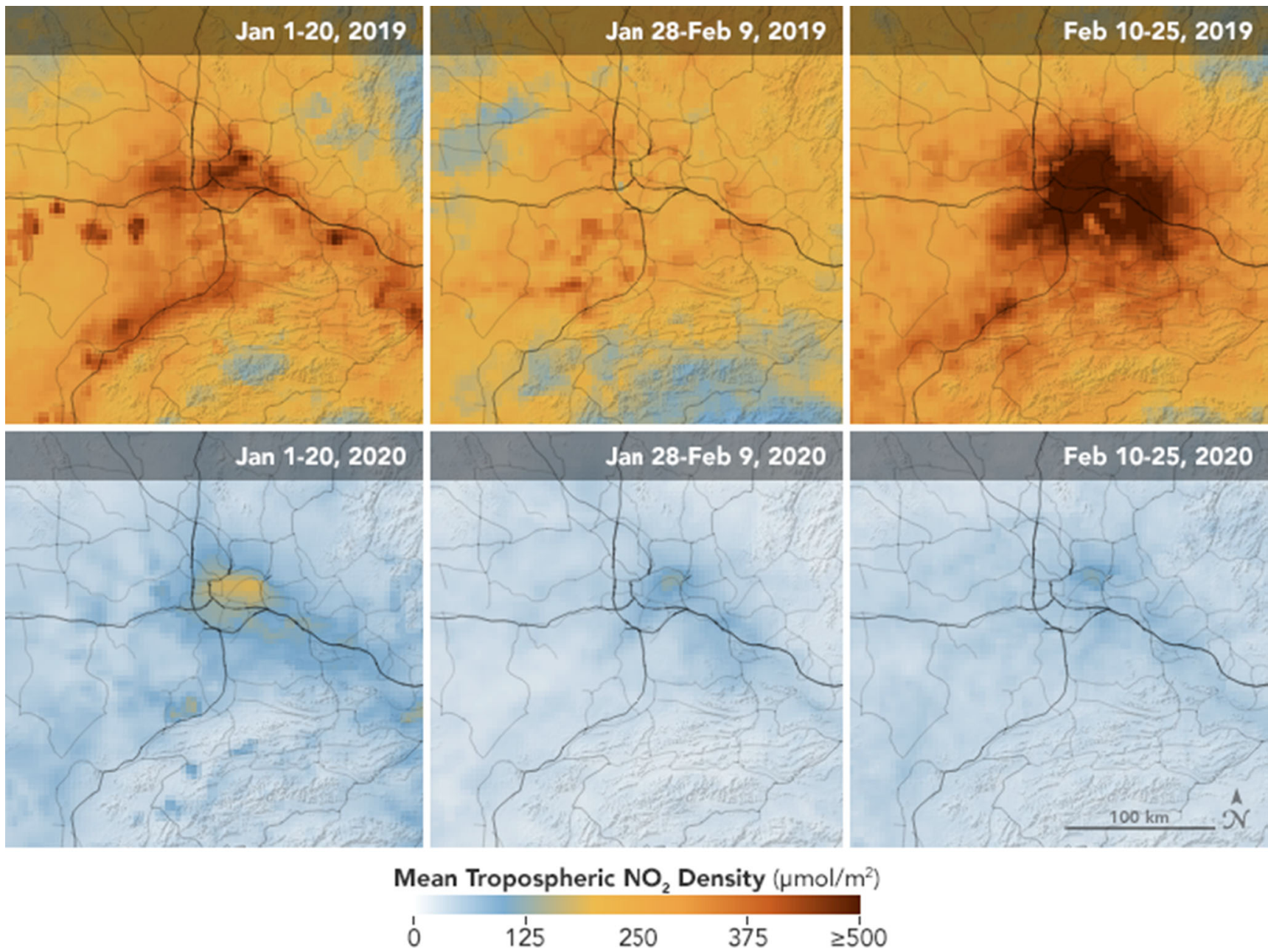

(c)

Fig. 14 continued.

of lockdown on air quality. From Fig. 9, it is clear that during the lockdown period, the air quality is improved for all the cases and this trade is followed up by maximum places in the world.

Nitrogen dioxide is one of the air pollutants that has shown its impact on European countries. Paris, Madrid, Milan, and Rome are the mostly affected areas in Europe due to nitrogen dioxide concentration, but during the lockdown period, the percentage of the pollutant has drastically decreased (air pollution remains low as Europeans stay at home 2020). As per Fig. 10, in March-April 2019, the effect of the pollutant was very high, but in March-April 2020, the effect of the same pollutant has been decreased in the same parts due to the lockdown.

In the previous section, it has already been observed that the AQI has improved in the lockdown period by considering all the air pollutants. For checking the effectiveness of the calculated AQI (shown in the Data collection and analysis section), real-time data has also been taken which is shown in this part of the study. The nitrogen dioxide concentration before and during lockdown has been shown in Figs. 11, 12, and 13 for France, Italy, and the northeast United States respectively (ESA and the COVID-19 pandemic 2020; Coronavirus lockdown leading to drop in pollution across Europe 2020; What impact will COVID-19 have on the environment? 2020). After the detailed study, it can be concluded that the $\mathrm{NO}_{2}$ concentration has decreased in all the cities around the globe, which is directly concerned with the betterment of the environment.

The coronavirus is discovered in the Wuhan province of China in the year 2019. After that, it has shown its enormous effect on the human body throughout the world. China is the first country in the globe that had declared a lockdown to prevent the spread of the coronavirus. After the strict lockdown implementation around China, the number of active COVID patients has decreased at a very high rate as well as 

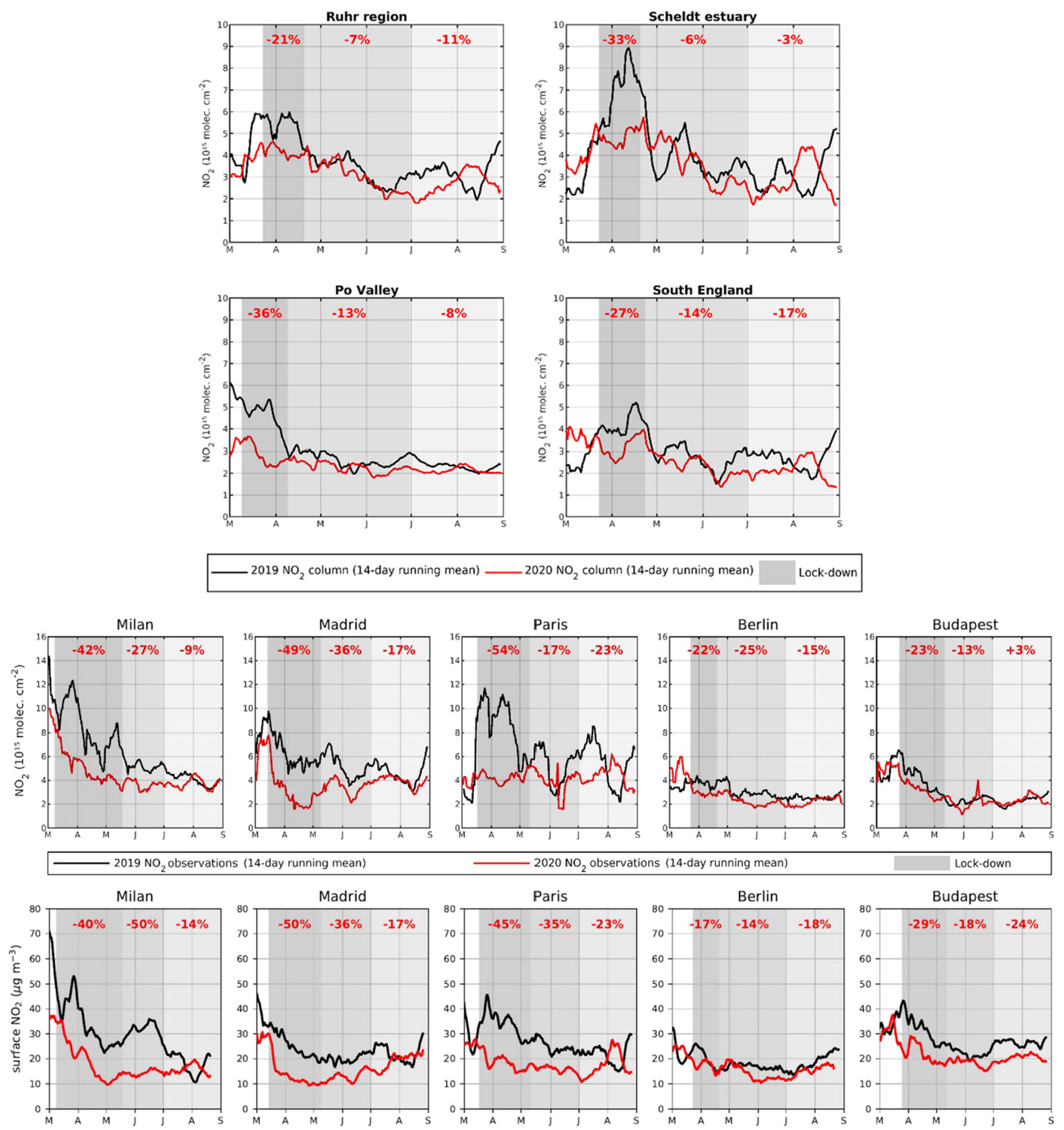

Fig. 15 Nitrogen dioxide concentrations over major European cities with and without lockdown

the environment is also improved (Airborne Nitrogen Dioxide Plummets Over China 2020; Air pollution returning to preCOVID levels 2020). The nitrogen dioxide concentration over China before and during lockdown is shown in Fig. 14.

Figure $14 \mathrm{c}$ has shown the effect of lockdown in the air quality based on $\mathrm{NO}_{2}$ concentration at Wuhan province of China. It can be concluded from the figure that the air quality is significantly improved in Wuhan which is in a similar direction as other cities in the world. The nitrogen dioxide concentrations over densely populated and industrialized areas of Europe (e.g., Ruhr region, Scheldt estuary, Po valley, South England, Milan, Madrid, Paris, Berlin, Budapest) are shown in Fig. 15. In the graph, "black" lines are presenting $\mathrm{NO}_{2}$ concentration during 2019, whereas "red" lines are showing 
April 2019

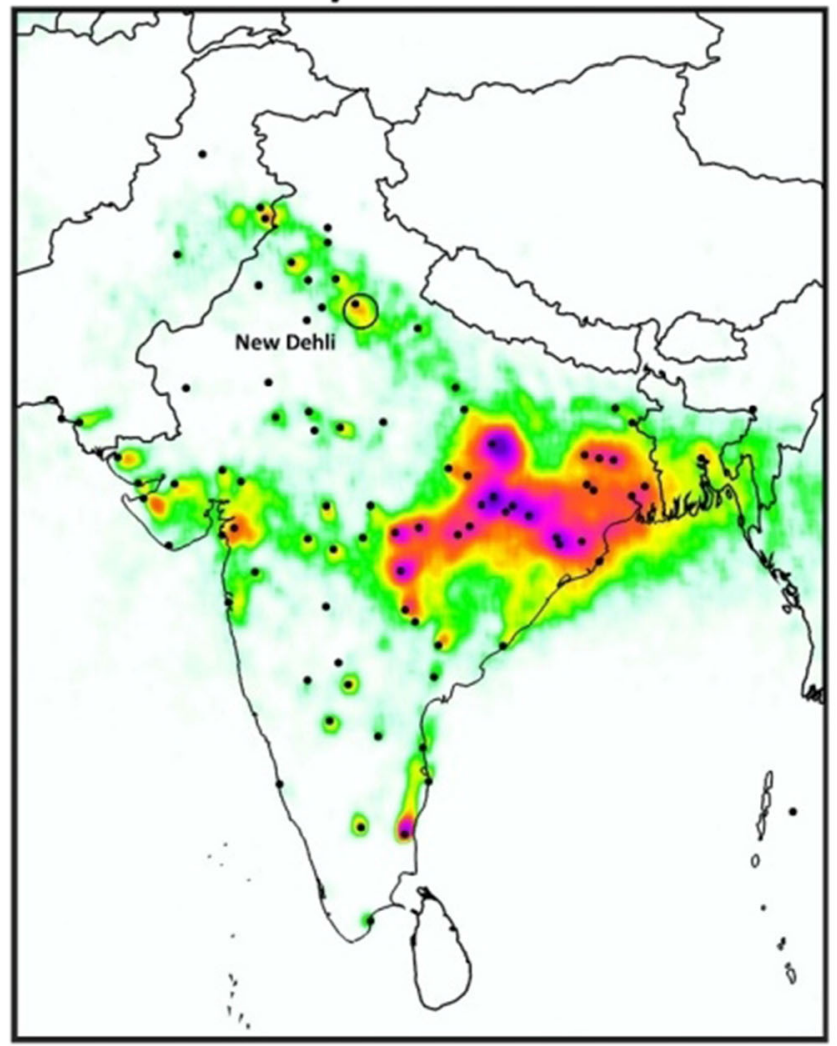

April 2020

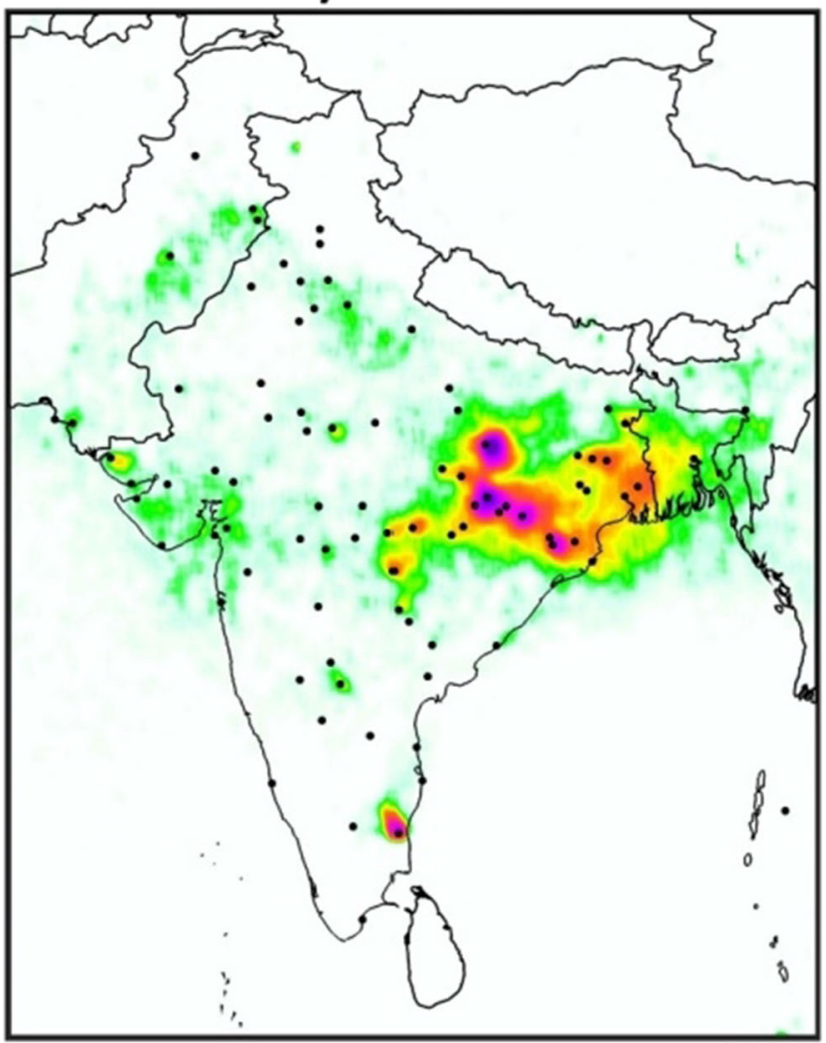

$\mathrm{SO}_{2}$ (DU)

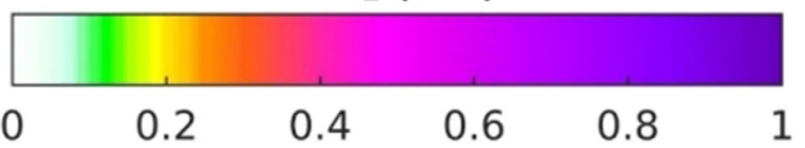

Fig. 16 Maps of sulphur dioxide concentrations over India in 2019 and 2020

$\mathrm{NO}_{2}$ concentration during 2020 (Air pollution in a postCOVID-19 world 2020). It is the most important observation that after lockdown, the $\mathrm{NO}_{2}$ concentration has drastically reduced in all the displayed places. Maximum figures portray the reduction of $\mathrm{NO}_{2}$ during the lockdown period, but all other air pollutants have also been reduced. If the air quality is improved then the health conditions of humans have also improved. The disease suffered by the human body can be also improved.

India is the second-most populous country in the world. As of 2020, the population density of India is very high with a value of 464 per $\mathrm{km}^{2}$. Due to the high rising nature of the corona virus, India is one of the most affected countries in the world due to a very high per capita population. The Government of India has imposed the lockdown on 23 March 2020 to prevent the spread of the corona virus.

Like other countries, the air pollutant concentration has decreased in India also with a high rate due to the lockdown. Figures 16 and 17 show the sulphur dioxide concentrations and airborne particle levels in India before and during lockdown conditions (ESA and the COVID-19 pandemic 2020; Airborne Particle Levels Plummet in Northern India 2020). From the figure, it can be concluded that the environment is pollution-free in the lockdown period in every region of India.

\section{Conclusion}

The COVID-19 pandemic forces to implement lockdown in almost all the countries around the globe. After the lockdown, the Air Quality Index noticeably reduces and the quality of air is improved in the whole world because of the more restricted activities of people; suspended transport services such as road, air, and rail; and shut down of maximum industries and educational institutions. In this paper, several scenarios have been taken for checking the impacts of lockdown on the air quality throughout the world. Finally, we would like to convey that the Air Quality Index and the corresponding health risk issues have 

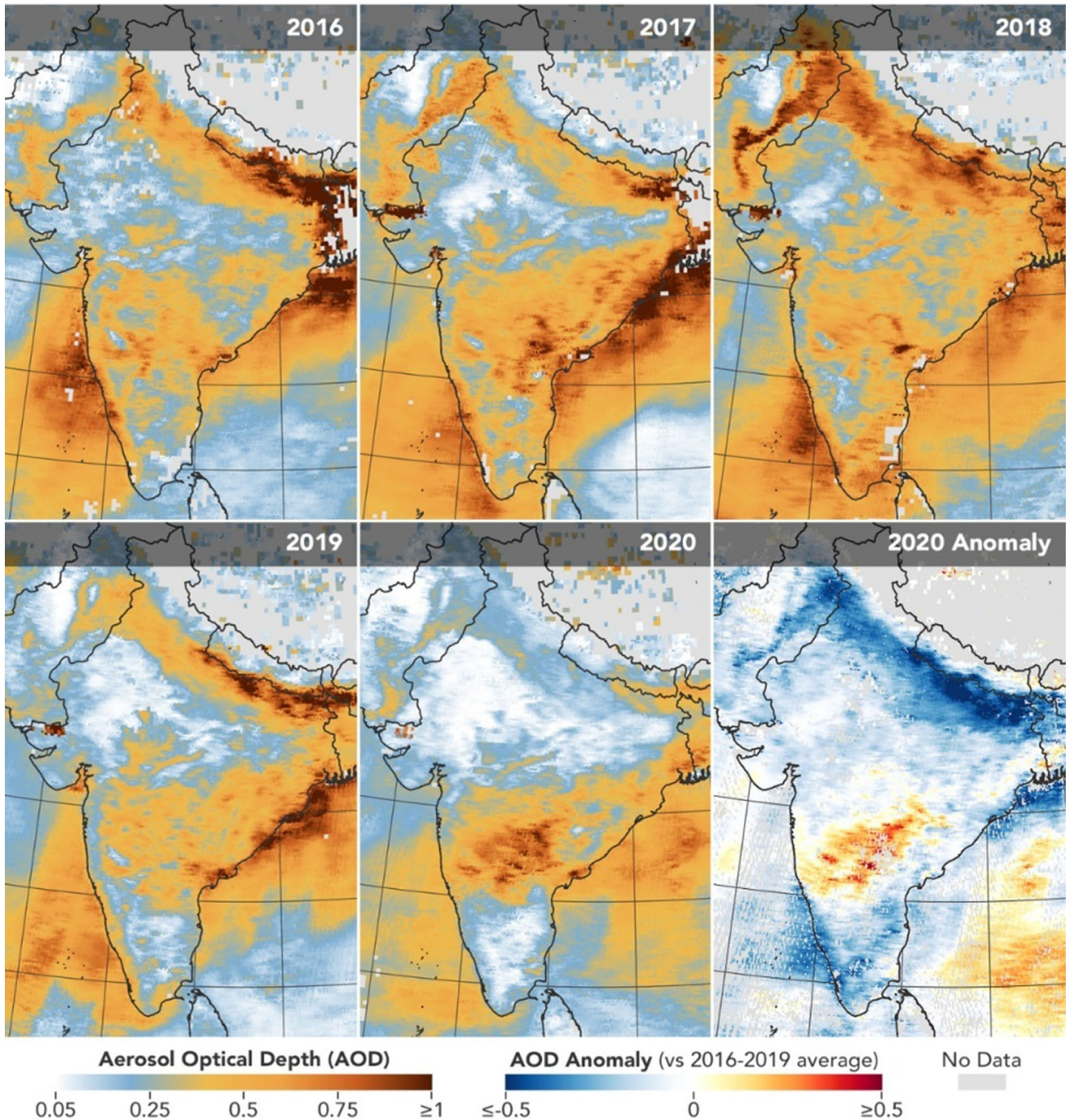

AOD Anomaly (vs 2016-2019 average)

No Data

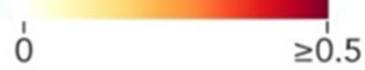

Fig. 17 Airborne particle levels plummet in Northern India

improved for the same cities during the lockdown condition compared to the without lockdown condition. To verify the AQI model, two parallel methods have been applied in this work. The raw data has been taken for calculating the AQI index, as well as some graphical data, which have been taken for comparison purposes. This study gives a very important lesson to us - if we need good health and better living, then we need to reduce the use of transport (if not required) and to focus on the alternative solution strongly to reduce the air pollution.

Acknowledgements We would like to thank the research team of Electrical Engg. Dept., Mizoram University, and research team of Electrical and Electronics Engg. Dept., Velagapudi Ramakrishna Siddhartha Engineering College, for their cooperation. 
Author contribution SG, SD, and SSD contributed to the study conception, data collection, and statistical analysis. All authors have written, read, and approved this manuscript for submission.

Data availability All data generated or analyzed during this study are included in this article.

\section{Declarations}

Ethics approval Not applicable.

Consent to participate Not applicable.

Consent to publish Not applicable.

Conflict of interest The authors declare no competing interests.

\section{References}

Abdullah S, Mansor AA, Napi NNLM, Mansor WNW, Ahmed AN, Ismail M, Ramly ZTA (2020) Air quality status during 2020 Malaysia Movement Control Order (MCO) due to 2019 novel coronavirus (2019-nCoV) pandemic. Sci Total Environ 729. https:// doi.org/10.1016/j.scitotenv.2020.139022

Air pollution in a post-COVID-19 world 2020 Available: https://www. esa.int/Applications/Observing the Earth/Copernicus/Sentinel-5P/ Air_pollution_in_a post-COVID-19_world

Air pollution remains low as Europeans stay at home 2020 Available: https:/www.esa.int/Applications/Observing the Earth/Copernicus/ Sentinel-5P/Air_pollution_remains_low_as_Europeans_stay_at home

Air pollution returning to pre-COVID levels 2020 Available: https:// www.esa.int/ Applications/Observing_the_Earth/Copernicus/ Sentinel-5P/Air pollution returning to pre-COVID levels

Airborne Nitrogen Dioxide Plummets Over China $20 \overline{20}$ Available: https://earthobservatory.nasa.gov/images/146362/airbornenitrogen-dioxide-plummets-over-china

Airborne Particle Levels Plummet in Northern India 2020 Available: https://earthobservatory.nasa.gov/images/146596/airborne-particlelevels-plummet-in-northern-india? $\mathrm{src}=\mathrm{ve}$

AirNow (2020) AQI Basics, Available: https://www.airnow.gov/aqi/aqibasics/

Hemant Bherwani, Saima Anjum, Suman Kumar, Sneha Gautam, Ankit Gupta, Himanshu Kumbhare, Avneesh Anshul and Rakesh Kumar 2020 "Understanding COVID- 19 transmission through Bayesian probabilistic modeling and GIS- based Voronoi approach: a policy perspective", Environment, Development and Sustainability. DOI: https://doi.org/10.1007/s10668-020-00849-0

Broomandi P, Karaca F, Nikfal A, Jahanbakhshi A, Tamjidi M, Kim JR (2020) Impact of COVID-19 event on the air quality in Iran. Aerosol Air Qual Res 20:1793-1804. https://doi.org/10.4209/aaqr.2020.05. 0205

Coronavirus lockdown leading to drop in pollution across Europe. 2020. Available: https://www.esa.int/Applications/Observing_the_Earth/ Copernicus/Sentinel-5P/Coronavirus_lockdown_leading_to_drop_ in pollution across Europe

Dantas G, Siciliano B, BoscaroFrança B, da Silva CM, Arbilla G (2020) The impact of COVID-19 partial lockdown on the air quality of the city of Rio de Janeiro, Brazil. Sci Total Environ 729. https://doi.org/ 10.1016/j.scitotenv.2020.139085

Deserted Venetian lagoon 2020 Available: https://www.esa.int/ESA Multimedia/Images Deserted_Venetian_lagoon
Dutheil F et al (2020) COVID-19 as a factor influencing air pollution? Environ Pollut 263. https://doi.org/10.1016/j.envpol.2020.114466

ESA and the COVID-19 pandemic 2020 Available: https://www.esa.int/ Enabling_Support/Preparing_for_the_Future/Space_for_Earth/ ESA and the COVID-19 pandemic.

Filonchyk M, Hurynovich V, Yan H, Gusev A, Shpilevskaya N (2020) Impact assessment of COVID-19 on variations of SO, NO, CO and AOD over East China. Aerosol Air Qual Res 20:1530-1540. https:// doi.org/10.4209/aaqr.2020.05.0226

Haines A, Amann M et al (2017) Short-lived climate pollutant mitigation and the Sustainable Development Goals. Nat Clim Chang 7:863869

IQAir (2020) Covid-19 Air Quality Report. https://www.iqair.com

Kerimray A, Baimatova N, Ibragimova OP, BauyrzhanBukenov, BulatKenessov PP, Karaca F (2020) Assessing air quality changes in large cities during COVID-19 lockdowns: the impacts of trafficfree urban conditions in Almaty, Kazakhstan. Sci Total Environ 730. https://doi.org/10.1016/j.scitotenv.2020.139179

Mahato S, Pal S, Ghosh KG (2020) Effect of lockdown amid COVID-19 pandemic on air quality of the megacity Delhi, India. Sci Total Environ 730. https://doi.org/10.1016/j.scitotenv.2020.139086

Manob D, Das A, Sarkar R, Saha S, Mandal A (2020) Examining the impact of lockdown (due to COVID-19) on ambient aerosols (PM2.5): a study on Indo-Gangetic Plain (IGP) Cities, India. Stochastic Environmental 660 Research and Risk Assessment. https://doi.org/10.1007/s00477-020-01905-x

Manob D, Das A, Ghosh S, Sarkar R, Saha S (2021) Spatio-temporal concentration of atmospheric particulate matter (PM2.5) during pandemic: a study on most polluted cities of indo-gangetic plain. Urban Clim 35. https://doi.org/10.1016/j.uclim.2020.100758

David Mintz (2016) Technical assistance documents for the reporting of daily air quality the Air Quality Index (AQI), United States Environmental Protection Agency, http:/www.epa.gov/airnow/ aqi-technical-assistance-document-dec2013.pdf

Muhammad S, Long X, Salman M (2020) COVID-19 pandemic and environmental pollution: a blessing in disguise. Sci Total Environ 728:1-5. https://doi.org/10.1016/j.scitotenv.2020.138820

Murray CJL (2019) Global, regional, 629 and national comparative risk assessment of behavioral, environmental and occupational, and metabolic risks or clusters of risks for 195 countries and territories, 1990-2017: a systematic analysis for the Global Burden of Disease Study 2017. Lancet 392:1923-1994. https://doi.org/10. 1016/S0140-6736(18)32225-6

National Air Quality Index 2020 Available: https://app.cpcbccr.com/ AQI India/

Pattanun A, Brauer M, Hystad P, Anenberg SC (2019) Global, national, and urban burdens of paediatric asthma incidence attributable to ambient $\mathrm{NO}_{2}$ pollution: estimates from global datasets. Lancet Planet Health 3:166-178. https://doi.org/10.1016/S2542-5196(19) 30046-4

Pratima K, Toshniwal D (2020a) Impact of lockdown measures during COVID-19 on air quality- a case study of India. International Journal of Environmental Health Research. https://doi.org/10. 1080/09603123.2020.1778646

Pratima K, Toshniwal D (2020b) Impact of lockdown on air quality over major cities across the globe during COVID-19 pandemic. Urban Clim 34. https://doi.org/10.1016/j.uclim.2020.100719

Ramesh P S, Chauhan A (2020) Impact of lockdown on air quality in India during COVID-19 pandemic. Air Quality, Atmosphere \& Health (Springer) 13:921-928

S J, Sharma T (2020) Social and travel lockdown impact considering coronavirus disease (COVID-19) on air quality in megacities of India: present benefits, future challenges and way forward. Aerosol Air Qual Res 20:1222-1236. https://doi.org/10.4209/aaqr. 2020.04.0171 
Sahoo PK, Chauhan AK, Mangla S, Pathak AK, Garg VK (2020a) COVID-19 pandemic: an outlook on its impact on air quality and its association with environmental variables in major cities of Punjab and Chandigarh, India. Environ Forensic. https://doi.org/10.1080/ 15275922.2020 .1836082

Sahoo PK, Mangla S, Pathak AK, Salãmao GN, Sarkar D (2020b) Pre-topost lockdown impact on air quality and the role of environmental factors in spreading the COVID-19 cases - a study from a worst-hit state of India. International Journal of Biometeorology. https://doi. org/10.1007/s00484-020-02019-3

Sharma S, Zhang M, Anshika JG, Zhang H, Kota SH (2020) Effect of restricted emissions during COVID-19 on air quality in India. Sci Total Environ 728. https://doi.org/10.1016/j.scitotenv.2020.138878

Singh RK D Chakraborty (2020) World's D 692 dirtiest air gets cleaner after India's lockdown. https://www.bloomberg.com/news/articles/ 2020-04-07/world-s-dirtiest-air-gets-cleaner-after-india-slockdown.

Tobías A, Carnerero C, at el. (2020) Changes in air quality during the lockdown in Barcelona (Spain) one month into the SARS-CoV-2 epidemic. Sci Total Environ 726:1-4. https://doi.org/10.1016/j. scitotenv.2020.138540
What impact will COVID-19 have on the environment? 2020. Available: https://www.science.org.au/curious/earth-environment/whatimpact-will-covid-19-have-environment

WHO (2020) Q\&A on corona-viruses (COVID-19). World Health Organization. https://www.who.int/news- room/q-a-detail/q-acoronaviruses

Worldometer (2020) COVID-19 coronavirus pandemic. https://www. worldometers.info/coronavirus/

Xu K, Cui K, Young LH, Hsieh YK, Wang YF, Zhang J, Wan S (2020) Impact of the COVID-19 event on air quality in central China. Aerosol Air Qual Res 20:915-929. https://doi.org/10.4209/aaqr. 2020.04.0150

Yaron O (2020) Assessing nitrogen dioxide (NO2) levels as a contributing factor to coronavirus (COVID-19) fatality. Sci Total Environ 726:1-5. https://doi.org/10.1016/j.scitotenv.2020.138605

Zalakeviciute R, Vasquez R, Bayas D, Buenano A, Mejia D, Zegarra R, Diaz A, Lamb B (2020) Drastic improvements in air quality in Ecuador during the COVID-19 outbreak. AerosolAir Qual Res 20: 1783-1792. https://doi.org/10.4209/aaqr.2020.05.0254

Publisher's note Springer Nature remains neutral with regard to jurisdictional claims in published maps and institutional affiliations. 